\title{
Influence of hydrothermal activity on the mineralogical-petrophysical properties of an atypical doleritic reservoir rock: A case study of the Gabes Gulf (north Africa, Tunisia)
}

\author{
Hanene Matoussi Kort ${ }^{\mathrm{a}, *}$, Ruth Hinrichs ${ }^{\mathrm{b}}$, Ahmed Abd Elmola ${ }^{\mathrm{c}}$, Néjia Laridhi Ouazaa ${ }^{\mathrm{a}}$, \\ Emmanuel Alexis Lalla ${ }^{\mathrm{d}}$, Asma Ben Saleh ${ }^{\mathrm{a}}$, Sonia Ben Alaya ${ }^{\mathrm{e}}$, Moncef Saidi ${ }^{\mathrm{e}}$ \\ ${ }^{a}$ Laboratory Geosciences, Mineral Resources, Energy and Environment (L.G.R.M.E.E.) Campus University Farhat Hachad, University of Tunis El Manar II, 2092, Faculty \\ of Sciences, Tunis, Tunisia \\ ${ }^{\mathrm{b}}$ Instituto de Geociências, Universidade Federal Do Rio Grande Do Sul, Av. Bento Gonçalves 9500, PO Box 15001, 91501-970, Porto Alegre, RS, Brazil \\ ${ }^{\mathrm{c}}$ IC2MP - UMR 7285 - CNRS, Université de Poitiers, Rue Michel Brunet, F-86073, Poitiers Cedex 9, France \\ ${ }^{\mathrm{d}}$ Centre for Research in Earth and Space Science, York University, Petrie Science Building, 4700Keele St, Toronto, M3J 1P3, Ontario, Canada \\ ${ }^{\mathrm{e}}$ ETAP, Tunisian Company of Petroleum Activity, Tunis, Tunisia
}

\section{A R T I C L E I N F O}

\section{Keywords:}

Gabes gulf

Tunisia

Magmatic intrusion

Hydrothermal alteration

Porosity-permeability

\begin{abstract}
A B S T R A C T
The Gabes Gulf located in the South Mediterranean Sea (Southeastern part of Tunisia) is a prolific petroleumproducing area with several oil and gas fields and it's the subject of significant discoveries. The area is affected by intense tectonic events and several stages of hydrothermal activities. During drilling at the MX area in NE of the Gabes Gulf, a magmatic intrusion has been encountered within a reservoir rock (i.e., Douleb Formation). The objectives of the present study are (1) to investigate the impact of the hydrothermal activities on this magmatic intrusion and (2) to characterize the potential modifications in its mineralogy and petro-physical properties that can affect the migration/accumulation of hydrocarbons. To do so we combine optical microscopy, X-ray diffraction, scanning electron microscopy, energy dispersive X-ray spectrometry, micro-Raman spectroscopy, electron microprobe analyses, and petro-physical measurements.

Our results show that the initial magmatic intrusion (dolerite) is composed mainly of plagioclase, clinopyroxene, and olivine. Based on petrographic observations, this intrusion subjected to several stages of hydrothermal fluid alterations that modified the primary texture and mineralogy. Albite, calcite, ankerite, dolomite, pyrite, quartz, anatase, kaolinite, and chlorite are the main secondary mineral products. During this alteration process, carbonates, pyrite, and quartz precipitated in vesicles, forming amygdules structure with enveloped zones indicating a fluctuation of fluid chemistry during their formation. In addition, petrographic observations indicate an interaction between feldspars exsolution and metasomatic processes in the studied area.

The dissolution mechanisms, as well as the textural modifications in the dolerite induced by the hydrothermal activity, are underlined by the presence of spherulites, pores, and micropores. Such modifications significantly improved the porosity of the dolerite body. Conversely, the new mineralization that filled the fractures and micro-fractures, have reduced the inter-pore connections, and thus reduced its permeability. The present work demonstrates the important role of hydrothermal activity on the petro-physical properties of magmatic intrusions and how it could facilitate the migration/accumulation of hydrocarbons. Our results open the door for further investigations to check the potential presence of hydrocarbons within this doleritic intrusion.
\end{abstract}

\section{Introduction}

The Tunisian Eastern margin and the Pelagic Sea are prolific petroleum-producing areas with very large proven oil and gas reserves
(Fig. 1) with significant potential for new discoveries. The focus of the present study is the MX area situated NE of the Gabes Gulf that contains a gas-condensate at three levels within the Cretaceous sedimentary sequence (Figs. 2 and 3). Hydrocarbons are found in several reservoirs in

\footnotetext{
* Corresponding author.

E-mail address: hanen.kortmattoussi@gmail.com (H. Matoussi Kort).
} 


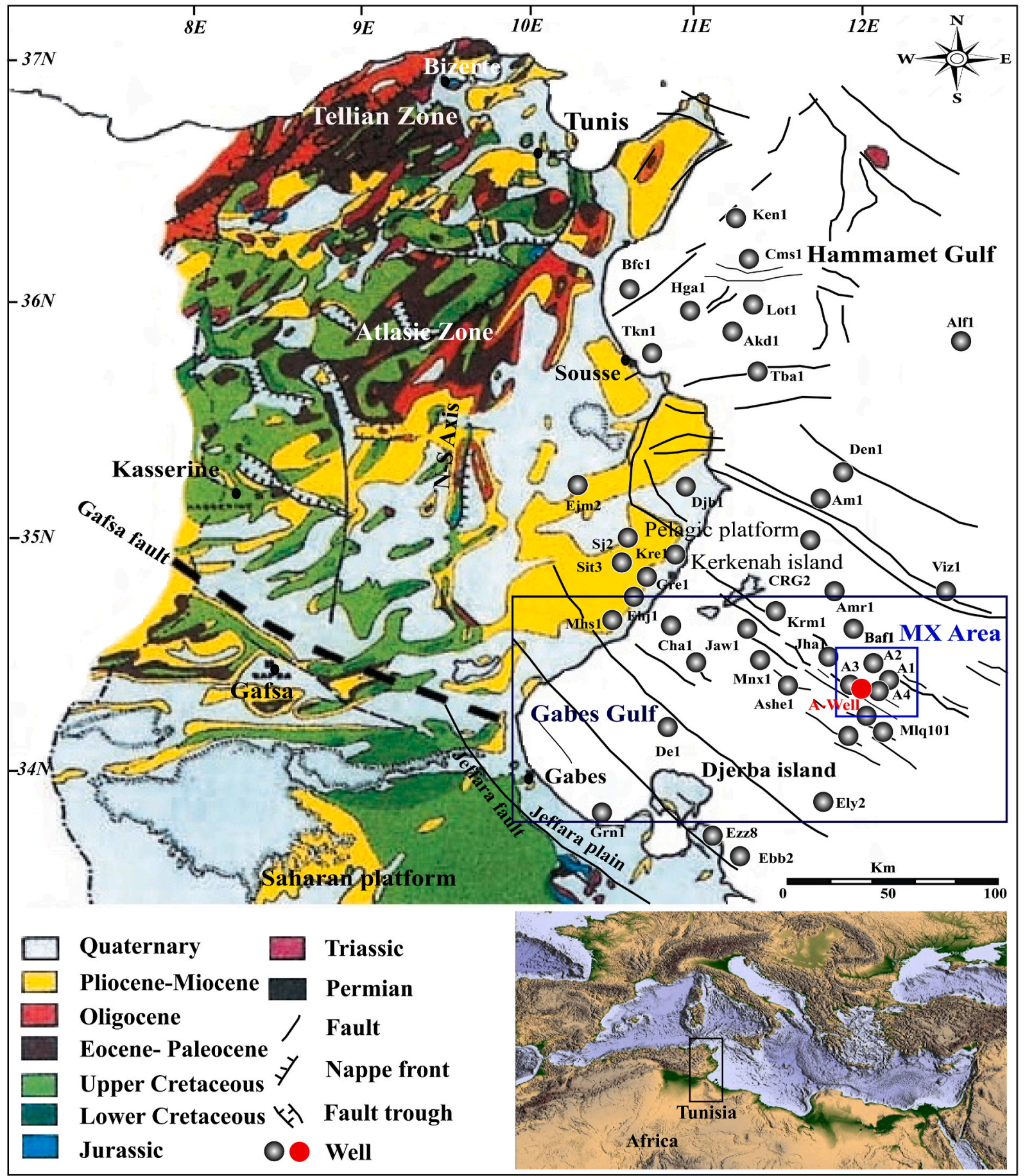

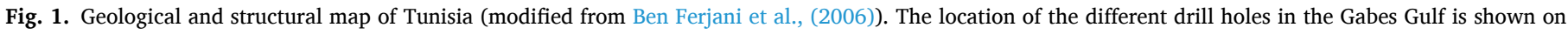
the map.

the MX area such as the Abiod Formation (Campanian), the Douleb; R1 inferior and R1 Superior (Late-Middle Turonian), and the Bireno (Middle-Early Turonian) members of the Aleg Formation (Fig. 3). The general structure in the field is that of a horst structure, divided into north and south compartments (Fig. 4). At the Abiod level, the reservoir has been eroded away to the north, but at the other levels, the reservoirs are dipclosed to the North and the South, and fault bound to the east and west. From a sedimentary perspective, the reservoirs are characterized by distinctly different facies reflecting different eustatic and paleoclimatic conditions as described below (Reservoirs Inc., 1990):
- The Abiod chalk reservoir was deposited on a distal carbonate ramp. It is composed of fine-grained limestone (foraminiferal nannofossil chalks with wackestone to packstone textures). Bioturbation features are common in some intervals. Porosity is generally high (mainly microporosity); ranging from 8 to $32 \%$, whilst permeability is low; ranging from 0,001 to $7.5 \mathrm{mD}$.

- The Douleb reservoir is divided into R1 Inferior and R1 Superior (Fig. 3). The R1 Inferior reservoir is a shallowing upwards sequence with depositional environments ranging from offshore to lagoonal and evaporites (Fig. 5). The overlying R1 Superior reservoir is the result of a transgression that drowned the island and consisted of mid 


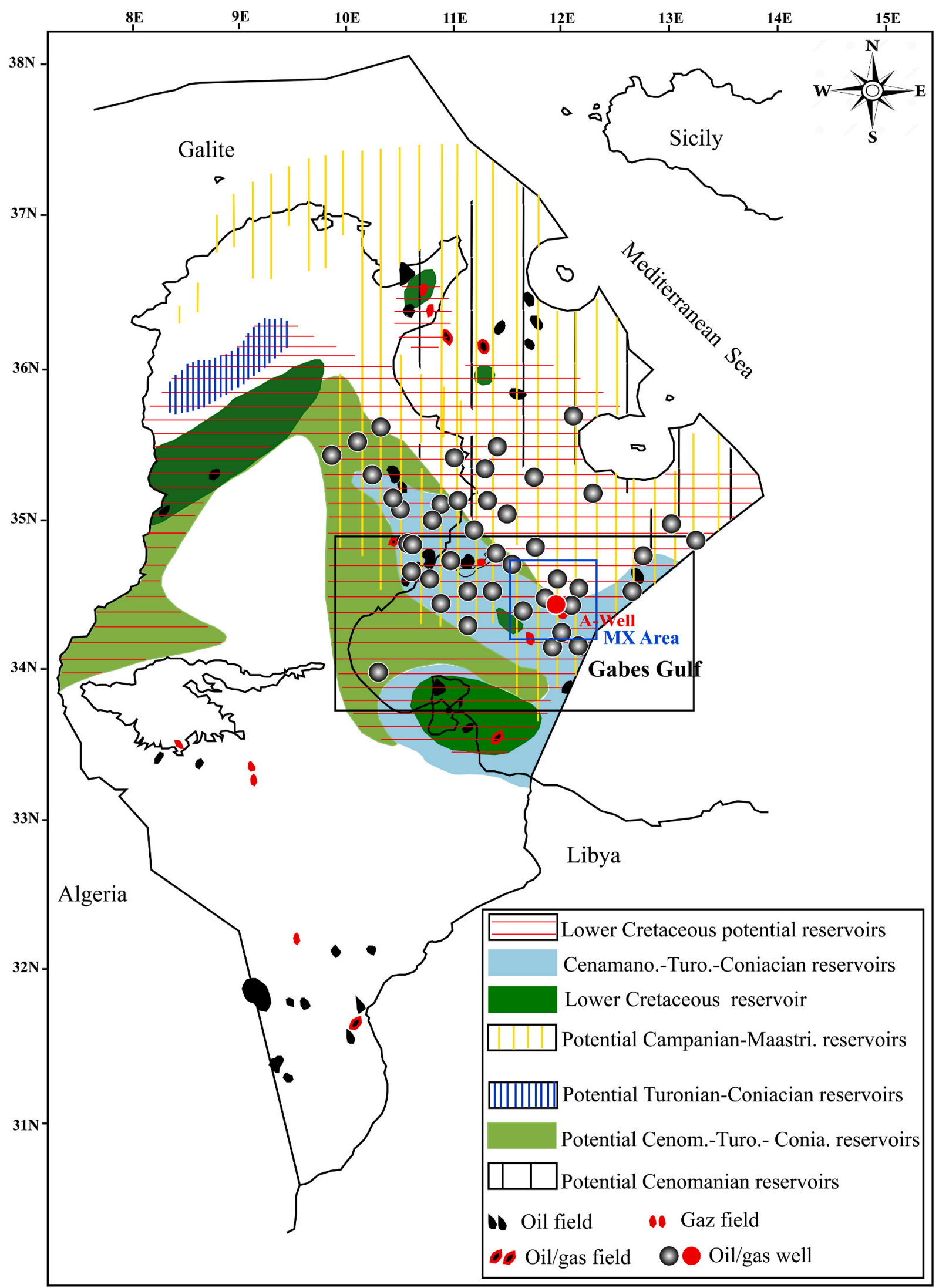

Fig. 2. Showing the different Cretaceous reservoirs in the studied area (from ETAP, (2006)). 


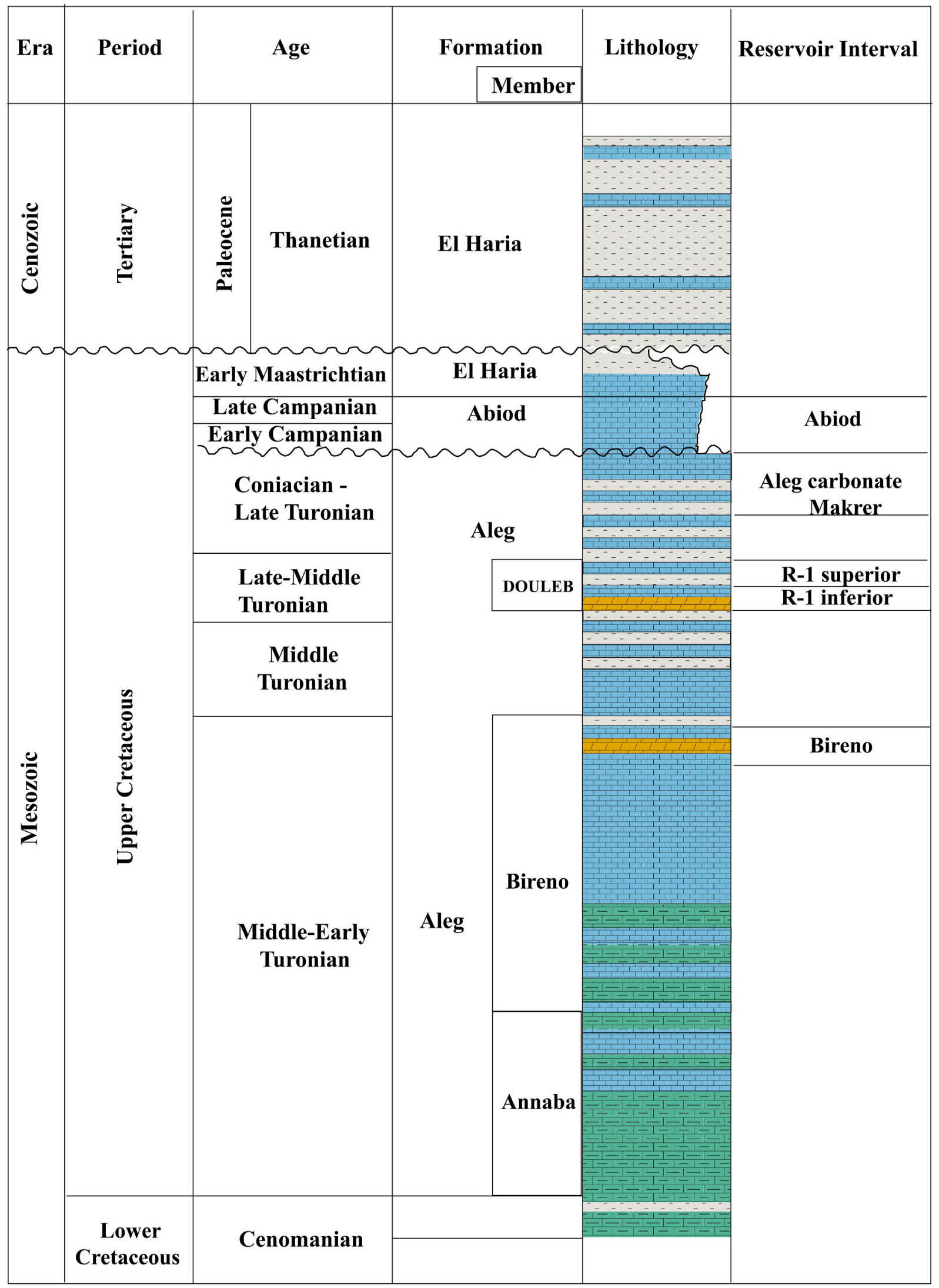

\section{Limestone Clayey limestone}

Fig. 3. Synthetic stratigraphic column illustrating the stratigraphy and the reservoir intervals of the MX area. 


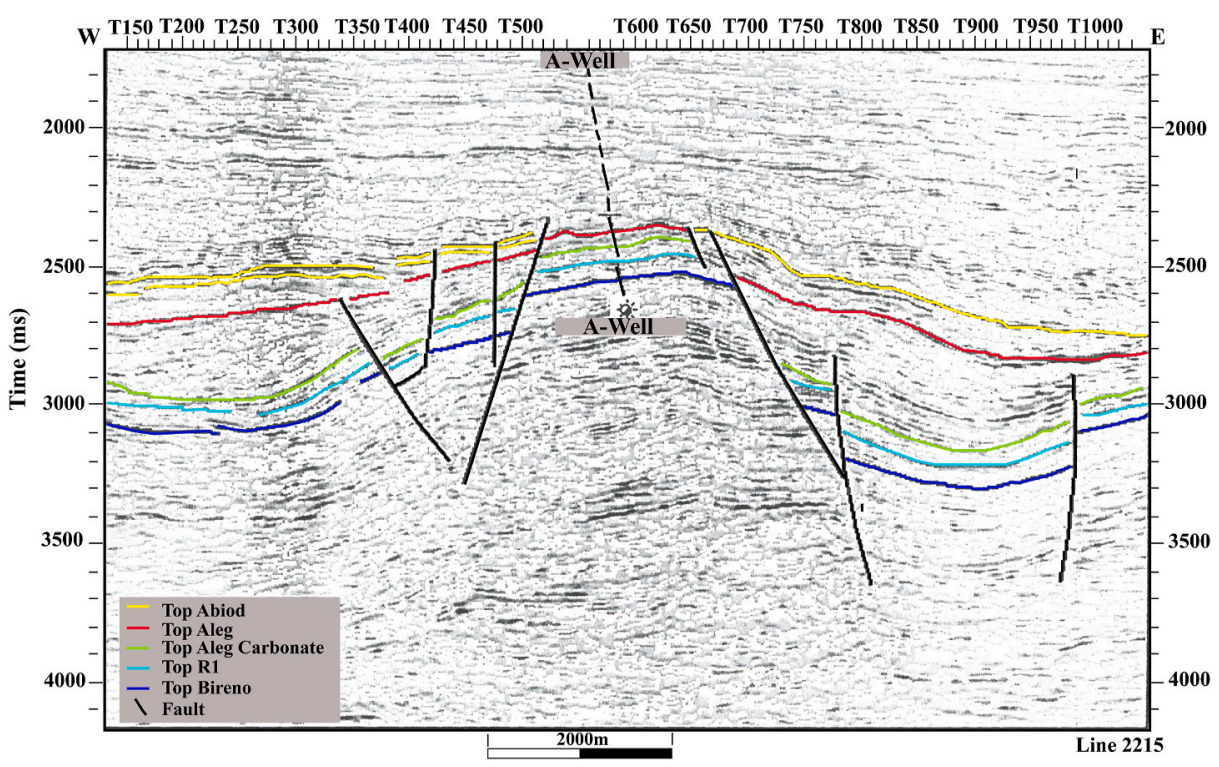

Fig. 4. Seismic profile in the Gabes Gulf showing synsedimentary normal faults, graben, and horst structures (Cook and Wright, 1998).

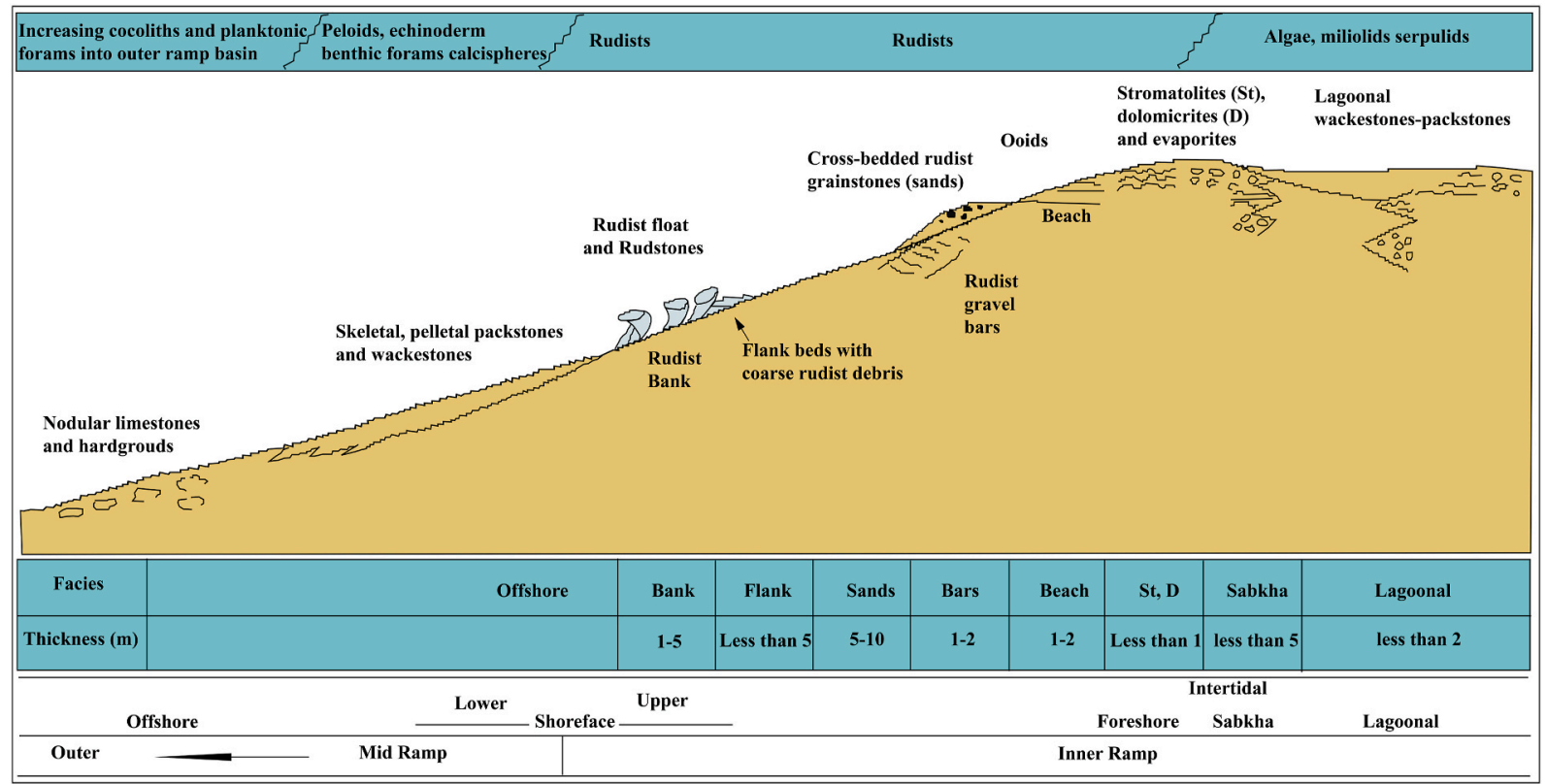

Fig. 5. A facies model for the Douleb reservoir (R1 Superior and R1 Inferior) in the MX area (modified from Cook and Wright (1998)).

to outer ramp facies. Porosity and permeability are best developed within the R1 Inferior reservoir. In the upper shoreface, grainstone porosity reaches $25 \%$ and permeability ranges from 10 to $1000 \mathrm{mD}$. The intergranular porosities are abundant and early meteoric cementation has partially occluded the porosity. Dolomitization has also increased the porosity and permeability in many units. Within the R1 Superior, porosity is mainly developed within the interbedded pack-wakestones where values are less than $15 \%$. The porosity is typically microporosity within the micrite pellets and micritized bioclasts, but with low permeability.

- The Bireno reservoir was deposited in a deeper water outer shelf or mid to outer ramp setting. The facies in this reservoir comprise calcispheric, peloidal wackestone, and packstones with varying amounts of bioturbation and clay content. The porosity in the Bireno reservoir reaches $27 \%$, but the permeability is generally less than $10 \mathrm{mD}$.
Table 1

General characteristic of the MX area reservoirs. The net to gross, porosity and water saturation are the average of the petrophysical values.

\begin{tabular}{lllll}
\hline Reservoir & Abiod & R1 Superior & $\begin{array}{l}\text { R1 } \\
\text { Inferior }\end{array}$ & Bireno \\
\hline Depth to crest (m) & 2.870 & 3.025 & 3.100 & 3.324 \\
Thickness (m) & 69 & 68 & 26 & 39 \\
Environment & Outer & Emergent to & Inner & Mid to \\
& ramp & outer ramp & ramp & outer ramp \\
Net to gross \% & 86 & 28 & 87 & 39 \\
Porosity (\%) & 25 & 11 & 14 & 13 \\
Water saturation (\%) & 15 & 23 & 10 & 40 \\
$\begin{array}{c}\text { Condensate/gas ratio } \\
\quad \text { bbl/mmscf }\end{array}$ & 20 & 16 & 16 & 55 \\
$\begin{array}{c}\text { Average well flow } \\
\text { rate mmscf/d }\end{array}$ & 23 & & & \\
\hline
\end{tabular}




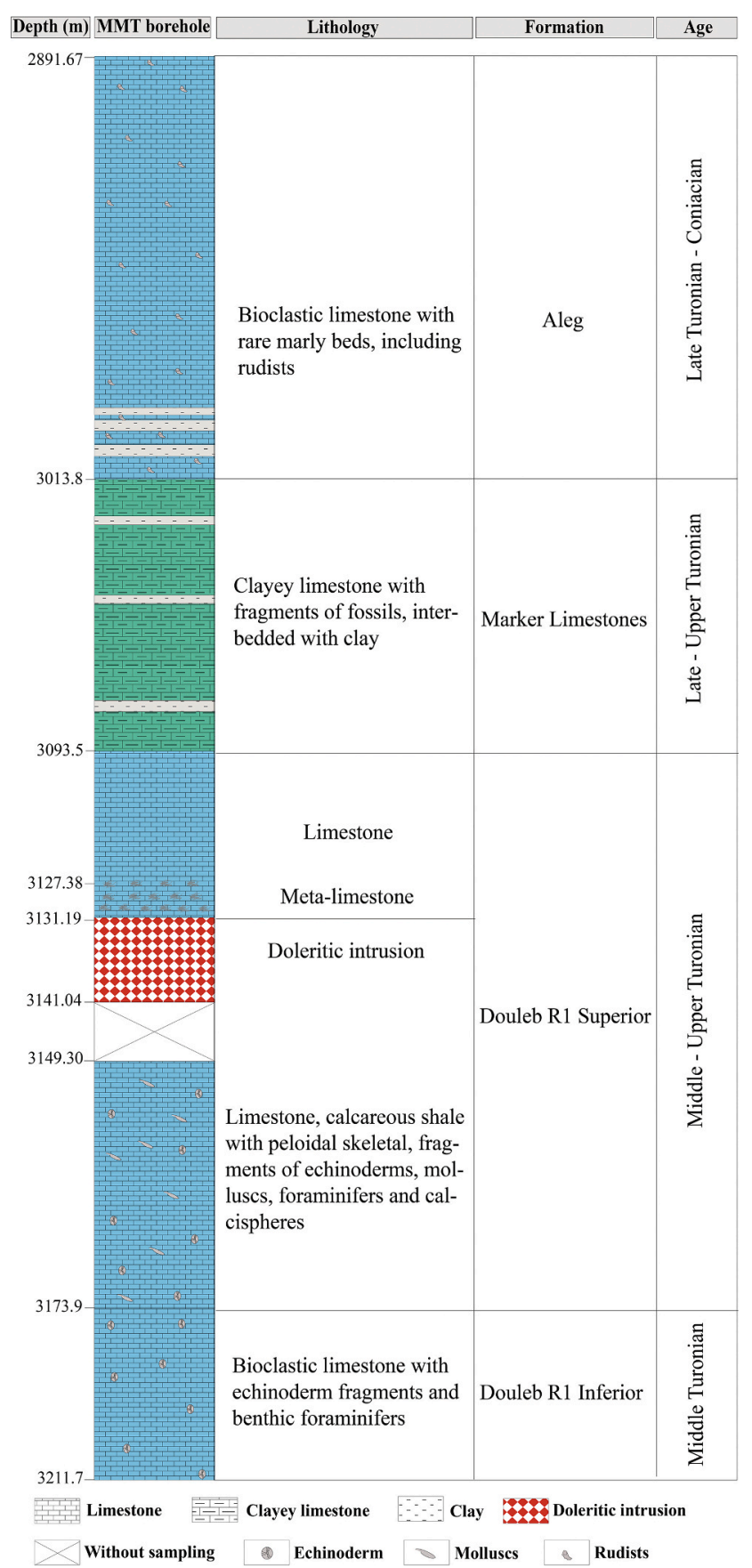

Fig. 6. Lithostratigraphy and age attribution of the doleritic intrusion and enclosing sedimentary pile in the studied A-well in the NE part of Gabes Gulf.

The gas-condensate within the MX area varies between reservoir intervals from 55 to $16 \mathrm{bbl} / \mathrm{mmscf}$ (Table 1). Voluminous Cretaceous subsurface magmatism took place in several localities in the Tunisian Eastern margin (Laridhi-Ouazaa, 1994; Matoussi Kort et al., 2009, 2015, 2015; Ben Saleh, 2015). This mafic magmatism is regularly present as lava flows, intrusions, and pyroclastic materials, which were recorded at different cretaceous lithostratigraphic intervals. The spatiotemporal distribution of this magmatism indicates its close association with the major fault corridors, which were reactivated by regional constraints (Laridhi Ouazaa and Bédir, 2004). These magmatism structures are found alongside deeply rooted faults. The emplacement of this magmatic activity generated a circulation of hydrothermal fluids that resulted in a local abnormal geothermal gradient (Laridhi-Ouazaa, 1994; Matoussi Kort, 2008). The temperature increment and the variable hydrothermal fluids have led to a generation of new mineral paragenesis within the magmatic rocks and the enclosing sedimentary deposits (Matoussi Kort et al., 2015). Hydrothermal systems occur in variety of settings where hot volcanic rocks interact with water (Alt et al., 1986; Hedenquist and Lowenstern, 1994; Lowell et al., 1995). Special attention is given to this alteration when it affects igneous rock intrusions as it may have implications on its petro-physical properties. During drilling at the MX area, located NE of the Gabes Gulf, a magmatic intrusion has been encountered within the Douleb reservoir rock. Several drill holes that cover the area are shown in Fig. 1, an exceptional coring that covers the magmatic intrusion was performed only at the A-well (Figs. 1 and 2). The aim of the present work is to study the impact of this hydrothermal activity on the magmatic intrusion mineralogy and prove the potential impact in its petro-physical properties. To do that we have integrated subsurface data, core descriptions, chemical characterization, and petro-physical measurements on representative samples from the A-well that cover the magmatic intrusion (Fig. 6).

\section{Geological and tectonic-magmatic context}

The Gabes Gulf (Fig. 1) located in Southeastern Tunisia is separated from the Tunisian Atlas by the North-South Axis and by the Major Gafsa fault. Numerous geological and geophysical studies have been previously conducted in this region (Wildi, 1983; Touati, 1985; Bedir et al., 1992; Buness et al., 1992; Guiraud and Maurin, 1992; Bédir, 1995; Patriat et al., 2003; Gabtni et al., 2011; Khomsi et al., 2012; Dkhaili et al., 2015). The Gabes Gulf is a subsidence domain of the pelagic platform marking the sinking of the Saharian platform towards the central Mediterranean. The studied area is a vast trough (Sillon Tunisian) that extends between the Tunisian plateau and the coast of Jeffara. The Gabes Gulf is the result of the opening of the Neo-Tethys during successive periods, its tectonic history is summarized below:

- The area has experienced a NE-SW extension during the Triassic period. This extension is responsible for the subsidence of the Jeffara plain following a network of NW-SE faults (Castany, 1954; Tavarnelli et al., 2004; Taktak et al., 2010). During the Middle to Upper Triassic, the Gulf of Gabes basin was characterized by listric faults (Dey et al., 2002). These tectonic events are integrated into the E-W rifting phase that is the extensive phase responsible for the opening of Tethys at the beginning of the fragmentation of Pangea (Guiraud, 1998; Bouaziz et al., 2002; Boughdiri et al., 2007; de Lamotte et al., 2009; Frizon de Lamotte et al., 2011; Masrouhi and Koyi, 2012; Naji et al., 2018). The Gabes Gulf represents an oriental prolongation of the Tunisian trough and is characterized by subsidence from the Triassic until the Lower Cretaceous.

- The pre-middle Cretaceous substratum in the Gulf of Gabes is characterized by a system of extensional oblique-slip faults with NNESSW trending formed during an important regional subsidence during the Triassic and the Jurassic.

- Throughout the Upper Cretaceous, NNW-SSE trending extensional structures are developed (Philips and Beckett, 2000; Dkhaili et al., 2015). The Santonian-Campanian period is characterized by NW-SE Wrench-normal faulting, probably responsible for the NW trending (Dercourt et al., 1986).

- In the Uppermost Cretaceous and throughout the Paleocene, this area presented NE-SW trending, corresponding to a tectonic inversion.

Numerous authors (e.g., Buness et al., 1992; Laridhi-Ouazaa, 1994; Matoussi Kort et al., 2009; Gabtni et al., 2011)) proposed a crustal thinning in Eastern Tunisia, induced by the Tethyan rifting. This thinned crust was an area of upwelling mantle that favored the increase of isotherms and ascent of basaltic magmas (Laridhi-Ouazaa, 1994; Matoussi Kort et al., 2008, 2009). The spatial-temporal distribution of the magmatic flows during the Mesozoic and the Cenozoic, as well as their 

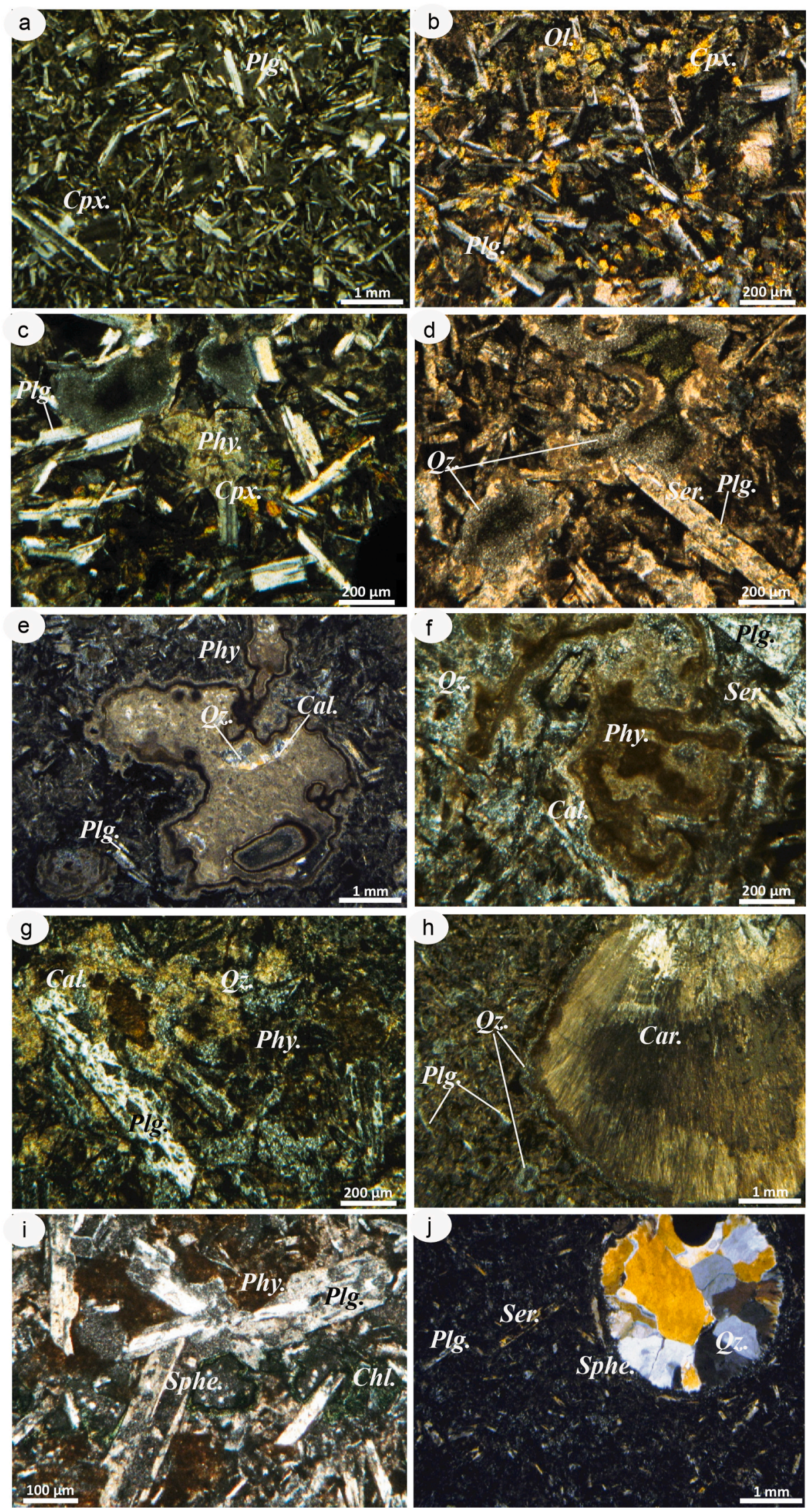

Fig. 7. Polarized light microscope images (crossed polars) of the Doleritic intrusion: a $(3140.47 \mathrm{~m})$ characterized by conservation of the magmatic structure with olivine, clinopyroxene, and plagioclase. b: $(3137.86 \mathrm{~m})$ tabular plagioclase with intragranular fractures and filled by sericite, clinopyroxene transformed to calcite, chlorite, and phyllitic products. c: (3137.39 m) Twinned plagioclase, Clinopyroxene, calcite, Pyllitics products with multiple spherulites filled by quartz and phyllitic products. d: (3135.77 $\mathrm{m}$ ) clinopyroxene disappears, a transformation of plagioclase to sericite with spherulite. e, f: (3134.94 m) transformation of the magmatic texture, multiple vesicles, and spherulite filled with a variety of quartz, calcite, and phyllitic products. g, h: $(3134.43 \mathrm{~m})$ altered plagioclase, spherulite of carbonate (dolomite/ankerite/calcite) with quartz rim. i: (3132.78 m) abundance of vesicles and spherulite with variable concentric envelopes. j (3131.67 m) some crystals of plagioclase completely transformed to albite, sericite, spherulite filled with calcite, quartz, and phyllitic products. Where $\mathrm{Ol}$. = olivine; $\mathrm{Cpx}$. = clinopyroxene; Plg. = plagioclase; Ser. = sericite; Cal. = calcite; Chl. = chlorite; Car. = carbonates; Phy. = phyllitic products; Qz. = quartz; Sphe. = spherulite. 
Table 2

An overview of the depth (m), age, and the description of the lithostratigraphic series crossed by A-well.

\begin{tabular}{|c|c|c|}
\hline Depth (m) & $\begin{array}{l}\text { Lithostratigraphic } \\
\text { age }\end{array}$ & Description \\
\hline $\begin{array}{r}2874.39 \mathrm{~m}- \\
3007.56 \mathrm{~m}\end{array}$ & $\begin{array}{l}\text { Late Turonian- } \\
\text { Coniacian }\end{array}$ & $\begin{array}{l}\text { Bioclastic limestone with rare marly beds, } \\
\text { including rudists. }\end{array}$ \\
\hline $\begin{array}{r}3007.56 \mathrm{~m}- \\
3093.5 \mathrm{~m}\end{array}$ & $\begin{array}{l}\text { Late-Upper } \\
\text { Turonian }\end{array}$ & $\begin{array}{l}\text { «Marker limestones » clayey limestones } \\
\text { with fragments of fossils, interbedded } \\
\text { with clay. }\end{array}$ \\
\hline $\begin{array}{l}3093.5 \mathrm{~m}- \\
\quad 3180.77 \mathrm{~m}\end{array}$ & $\begin{array}{l}\text { Middle-Upper } \\
\text { Turonian }\end{array}$ & $\begin{array}{l}\text { Douleb R1 superior reservoir. Thinly } \\
\text { interbedded argillaceous, slightly } \\
\text { limestone, calcareous shale with peloidal } \\
\text { skeletal fragments, mainly of } \\
\text { echinoderms, molluscs, forams, and } \\
\text { calcispheres. This reservoir is the result of } \\
\text { a transgression that drowned the island } \\
\text { and consists of mid to outer ramp facies. } \\
\text { This level embedded a magmatic interval } \\
\text { of } 9.85 \mathrm{~m} \text { thickness ( } 3131.19 \mathrm{~m}-3141.04 \\
\mathrm{~m}) \text {. With the contact of the magmatic } \\
\text { level, the limestones are transformed and } \\
\text { become meta-limestones. }\end{array}$ \\
\hline $\begin{array}{l}3180.77 \mathrm{~m}- \\
3223.61 \mathrm{~m}\end{array}$ & Middle Turonian & $\begin{array}{l}\text { Douleb R1 inferior reservoir. Bioclastic } \\
\text { limestone, dolomitized carbonates, } \\
\text { having brown to grey color constituting. } \\
\text { Generally, a coarsening upwards sequence } \\
\text { is seen beginning with offshore bioclastic } \\
\text { packstones and wackestones with peloids, } \\
\text { echinoderm fragments, bentic forams, and } \\
\text { calcispheres. This reservoir is a } \\
\text { shallowing upwards sequence with } \\
\text { environments ranging from offshore to } \\
\text { lagoons. }\end{array}$ \\
\hline
\end{tabular}

degree of evolution, is related to the repartition of sliding and ramified structures of major faults, bordering the different basin blocks of the Eastern Tunisian margin (Laridhi Ouazaa and Bédir, 2004; Matoussi Kort et al., 2015). In the MX area, the Cenomanian-Turonian-Coniacian period corresponds to the emplacement of intrusions, lava flows interbedded with breccias, volcanic microbreccia, and pyroclastic rocks.

\subsection{Overview of the upper cretaceous lithostratigraphic series in the A- well}

In the Gabes Gulf, there are no outcrops for the Cretaceous rocks, they are only studied on subsurface seismic sections or encountered in drilling boreholes. The sedimentary facies are strictly related to paleogeographic directions guided by the tectonic and the eustatic variations. The Upper Cretaceous rocks in the study area are mainly materialized by a Middle-Early Turonian «Bireno » member of the Aleg Formation and constituting the lower reservoir interval, was deposited in a deeper water outer shelf or mid to outer ramp setting. The Late Middle Turonian « Douleb », a member of the Aleg Formation, is composed of R1 Inferior and R1 Superior reservoirs. The Abiod Formation (CampanianEarly Maastrichtian) is represented by the "Chalk reservoir ». The lithostratigraphic series in the A-well are shown in Table 2 and Fig. 6.

\section{Materials and methods}

Samples have been collected from the A-well, which is a diverted drilling situated in the Pelagic Sea, NE part of the Gabes Gulf (Fig. 1). The A-well is among many other boreholes drilled in the MX area that crossed the magmatic rocks, however, the A-well is the only one that has been cored. The sample selection was made based on a thorough revision of the well reports and representative core samples of magmatic rocks from various selected depths. Thin sections were prepared for petrographic observations. The cores were first studied by an optical microscope (USB Digital Microscope ETAP), then many spot analysis measurements of the samples were performed by an electronic microprobe. This analysis was made using a CAMEBAX model SX 50 electronic microprobe at the University of Paris VI (France), using an operating voltage of $15 \mathrm{kV}$, a beam current of $10 \mathrm{nA}$, variable spot size, and $5 s$ net acquisition time. Powder X-ray diffraction of twenty selected core samples of the magmatic rocks was analyzed with a cobalt anticathode in a Bragg-Brentano diffractometer (Philips Panalytical X'pert PRO) (at the mineral resources and environmental laboratory-Geology Department-University of Sciences of Tunis El Manar-Tunisia). Selected core samples of various magmatic rocks were analyzed by scanning electron microscopy (SEM Jeol LV5800) and energy dispersive X-ray spectrometry (EDX $\mathrm{Si}$ (Li) Thermo-Noran) (Laboratório de Microanálise, Universidade Federal do Rio Grande do Sul, Porto Alegre, RS, Brazil).

To prove the alteration degree of the magmatic intrusion, three rock fragments from different depths $(3132.46 \mathrm{~m}, 3134.37 \mathrm{~m}$, and 3135.64 $\mathrm{m}$ ) were analyzed in detail by SEM-EDX. The samples were embedded in resin and polished, afterward covered with a nanometric carbon film. The analyses were performed at an acceleration voltage of $15 \mathrm{kV}$ and a working distance of $10 \mathrm{~mm}$. Composite maps were obtained overlaying the element distribution using the software "ImageJ". Microanalytical Xray spectra were also performed at some selected points. The Raman spectra were acquired on unpolished samples using the "crystal sleuth" software (at the American Mineralogist Crystal Structure Databases, RRUFF Project). Micro-Raman spectroscopy (Laboratório de Microanálise, UFRGS, Porto Alegre, RS, Brazil) was carried out using a $633 \mathrm{~nm}$ $\mathrm{He}-\mathrm{Ne}$ laser. Each spectrum was acquired with $5 \mathrm{~s}$ acquisition time on a 1-2 $\mu \mathrm{m}$ diameter of the sample. Minerals were identified using the RRUFF database and the Romanian Raman Database (Buzgar et al., 2009; Downs et al., 2015). 263 horizontal plugs distributed over the entire series were selected for the permeability measurements using a nitrogen permeameter (UltraPerm TM400) and for the porosity using a helium porosimeter "UtraPore TM 300".

\section{Results}

\subsection{Petrographic observations}

A detailed petrographic study was made on a magmatic level within the Douleb reservoir (A-well). This magmatic intrusion (from $3131.19 \mathrm{~m}$ to $3141.04 \mathrm{~m}) \sim 9.85 \mathrm{~m}$ thick is embedded in the Turonian limestone (Superior Douleb R1 reservoir). The magmatic intrusion is dolerite; having a fine texture with a glassy texture on the edges and there is a decrease in crystallinity from the center to the periphery. It is variably altered, having several colors: grey, green, reddish, and brown. Compared with the uppermost part, the basal part is compacted and hard, with a very fine-grained aspect. This intrusive dolerite is related to the presence of the deep-seated faults that define the studied area. This fissural magmatism can be materialized by intercalations within the sedimentary layers of the magmatic level. With the contact of this dolerite, the limestones have a grayish-white to pink color and are transformed and became meta-limestones. Similarly, in other parts of the region, carbonate rocks that are in contact with the magmatic rocks reveal dissolution and precipitation processes by metasomatic mechanisms of new minerals formation such as barite, scapolite, and pyrite in the microfracture of these limestones (Matoussi Kort et al., 2015). Microscopically, the doleritic intrusion shows a variable degree of alteration and texture with depth:

- Level $3140.47 \mathrm{~m}$ : is characterized by the persistence of magmatic texture (doleritic). Rare crystals of olivine, lath-shaped plagioclase crystals set in a finer matrix of clinopyroxene (Fig. 7a).

- Level 3137.86 m: Small sub-rounded olivine, tabular plagioclase displays intracrystalline fractures filled with sericite. Clinopyroxene crystals in the intercrystalline space, altered sometimes to chlorite, calcite, or layer silicates (Fig. 7b). 

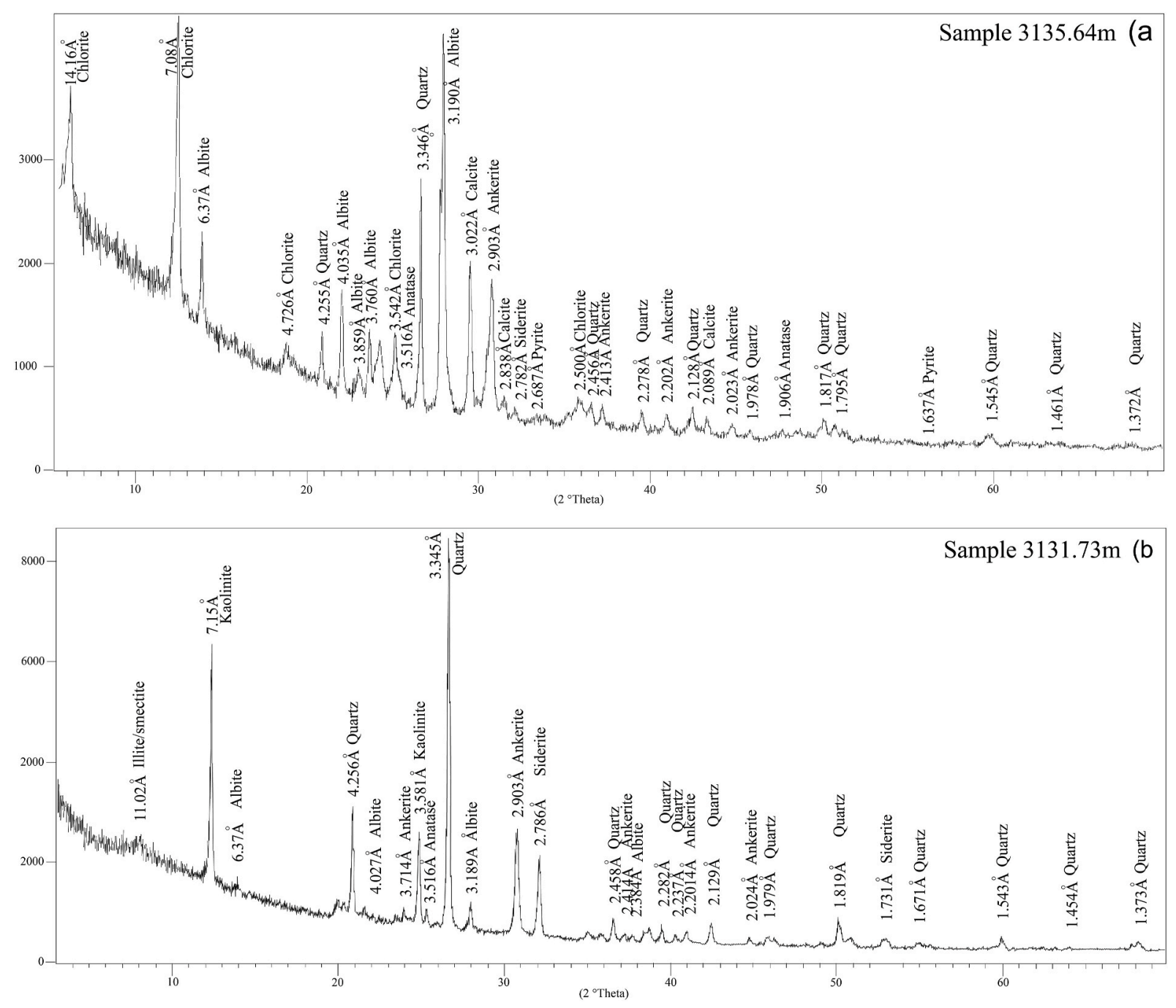

Fig. 8. XRD patterns of the doleritic intrusion. a: sample from $3135.64 \mathrm{~m}$ depth, b: sample from $3131.73 \mathrm{~m}$ depth of the A-well.

- Level 3137.39 m: Twinned plagioclase crystals, fractured clinopyroxene altered to chlorite, calcite, or layer silicates. Multiple vesicles filled with various minerals (Fig. 7c) indicate an earlier hydrothermal circulation.

- Level 3135.77 m: Primary magmatic texture is altered, clinopyroxene replaced by calcite and phyllosilicates. Crystals of plagioclase are partially transformed to sericite and calcite. More and more vesicles and quartz are observed (Fig. $7 \mathrm{~d}$ ).

- Level $3134.94 \mathrm{~m}$ : Laths of plagioclases completely transformed and without twinning. Multiple vesicles filled with quartz, calcite, and phyllosilicates (Fig. 7e and f).

- Level $3134.43 \mathrm{~m}$ : Altered plagioclase crystals, spherulites, and vesicles with variable diameters, filled with quartz and calcite (Fig. $7 \mathrm{~g}$ and $\mathrm{h}$ ).

- Level 3132.78 m: Composed of phyllosilicate products, plagioclase entirely transformed, more spherulites with variable concentric envelopes (Fig. 7i).

- Level $3131.67 \mathrm{~m}$ : Composed of abundant phyllosilicates and sericite. Plagioclase is completely transformed. Spherulites are filled with calcite, quartz, and sometimes phyllosilicates (Fig. 7j).

\subsection{Mineralogical and chemical composition}

\subsubsection{X-ray diffraction}

X-ray diffraction patterns (Fig. 8) confirmed the presence of quartz, calcite, dolomite, ankerite, albite, anatase, ilmenite, siderite, and pyrite as secondary mineral products of the hydrothermal alteration. In addition, the results show that the phyllosilicates in the majority of doleritic intrusion samples are kaolinite, chlorite, and minor illite-smectite mixed layers.

\subsubsection{Electronic microprobe analysis}

The petrographic study has been supplemented by a mineralogical analysis for the fresh crystals in the unaltered magmatic intrusion with an electronic microprobe. The clinopyroxenes are of the salites-augites type with $\mathrm{TiO}_{2}$ content ranging between $0.59 \%$ and $1.08 \%$. The plagioclases show composition varying from Labrador An62 to Andesine An35 (Fig. 9).

\subsubsection{Micro-Raman spectroscopy}

Micro-Raman analyses of some representative samples proved the absence of Raman bands at $1700 \mathrm{~cm}^{-1}$ which are typically used to determine if dolomite is a product of a biological alteration (Rividi et al., 2010; Sun et al., 2014). Silica was present in the form of $\alpha$-quartz; trigonal low-temperature form. Factor group analysis shows that quartz presents $8 \mathrm{E}+4 \mathrm{~A}_{1}$ vibrational modes. The most intense $\mathrm{A}_{1}$ vibrational band was detected at $465 \mathrm{~cm}^{-1}$. In some cases, the optical branch $\mathrm{E}_{(\mathrm{LO}+}$ то) at $127 \mathrm{~cm}^{-1}$, was detected, as well as $\mathrm{A}_{1}$ at $200 \mathrm{~cm}^{-1}$ and the $\mathrm{E}$ band at $493 \mathrm{~cm}^{-1}$ (Chemarin et al., 1996). The sample from the intermediate depth (3134.37 m) presents values of $\Delta \omega_{1}=-4$ and $\Delta \omega_{2}=1$, which can 


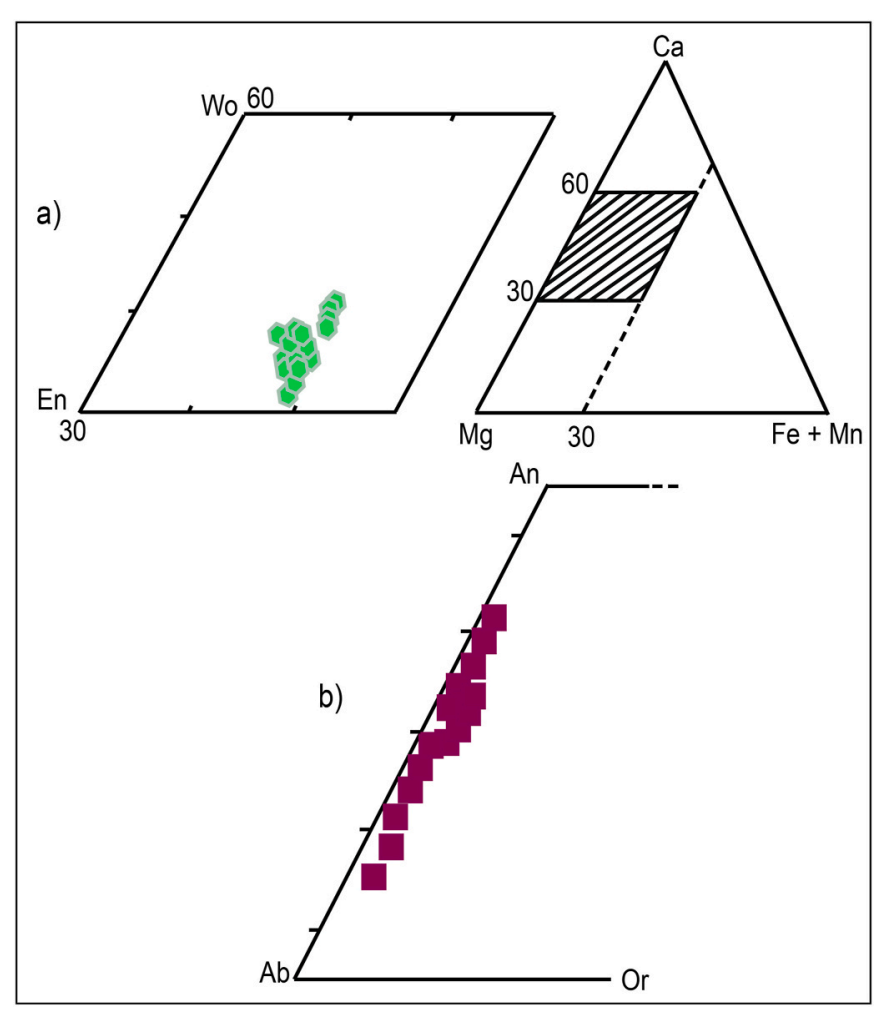

Fig. 9. Electronic microprobe analysis: a: the Hess diagram for clinopyroxenes, b: plagioclase composition variation of the doleritic intrusion that was crossed by A-well. be assigned to a crystal that retains tensile stress from its formation. The shallower sample $(3132.46 \mathrm{~m})$ presents similar results with $\Delta \omega_{1}=-2$, indicating remnants of residual stress. The $\mathrm{TiO}_{2}$ can present three polymorphs: rutile (tetragonal), brookite (orthorhombic), and anatase (tetragonal). In our case, Raman spectroscopy confirmed the predominance of anatase. The group analysis of anatase presents six modes $\left(\mathrm{A}_{1 g}\right.$ $+2 \mathrm{~B}_{1 \mathrm{~g}}+3 \mathrm{E}_{\mathrm{g}}$ ) that are Raman active and three inactive modes. These bands at 147, 198, 320, 398, 448, 515, 640, and $796 \mathrm{~cm}^{-1}, \mathrm{~A}_{1 \mathrm{~g}}$ being the $147 \mathrm{~cm}^{-1}$ bands (Balachandran and Eror, 1982). The three bands around 148,198 , and $640 \mathrm{~cm}^{-1}$ can be assigned to the $\mathrm{E}_{\mathrm{g}}$ vibrational modes. In different samples, the $E_{g}$ and the band at $398 \mathrm{~cm}^{-1}\left(B_{1 g}\right)$ were detected (Balachandran and Eror, 1982; Sekiya et al., 2001). The vibration at 511 $\mathrm{cm}^{-1}$ was only detected on the $3132.46 \mathrm{~m}$ sample.

\subsubsection{SEM-EDX}

In all the analyzed samples, the element distribution maps show that $\mathrm{Si}, \mathrm{Al}, \mathrm{Na}$, and $\mathrm{K}$ are grouped as silicates, while $\mathrm{Fe}, \mathrm{Ca}$ and $\mathrm{Mg}$ are present as carbonates. In the backscattered electron (BSE) images, the different shades of grey (different contrast) of the carbonates are due to different amounts of iron, calcium, and magnesium in the dolomite/ankerite/ calcite solid solution, where higher amounts of iron give the lightest shade of grey, and higher amounts of magnesium give the darkest shade. Fig. 10a shows the core fragment from $3132.46 \mathrm{~m}$ depth, the embedded and polished sample, indicating the location of the filled vesicles (spheroids). Dolomite is presented in the blue spheroid above region " $\mathrm{A}$ " on the polished sample (Fig. 10a). Calcite, dolomite, and ankerite spherulites are surrounded by a crown-shaped composed of quartz as shown in Fig. 10b. Fig. 10c presents a low magnification BSE image of this amygdule and the composition of the dark central area of the carbonate. The upper area is composed of carbonates with varying amounts of $\mathrm{Ca}, \mathrm{Mg}$, and $\mathrm{Fe}$ (calcite, dolomite, ankerite). The region between the two-carbonate amygdule with $\mathrm{SiO}_{2}$ rims in Fig. 10d (region "A" in

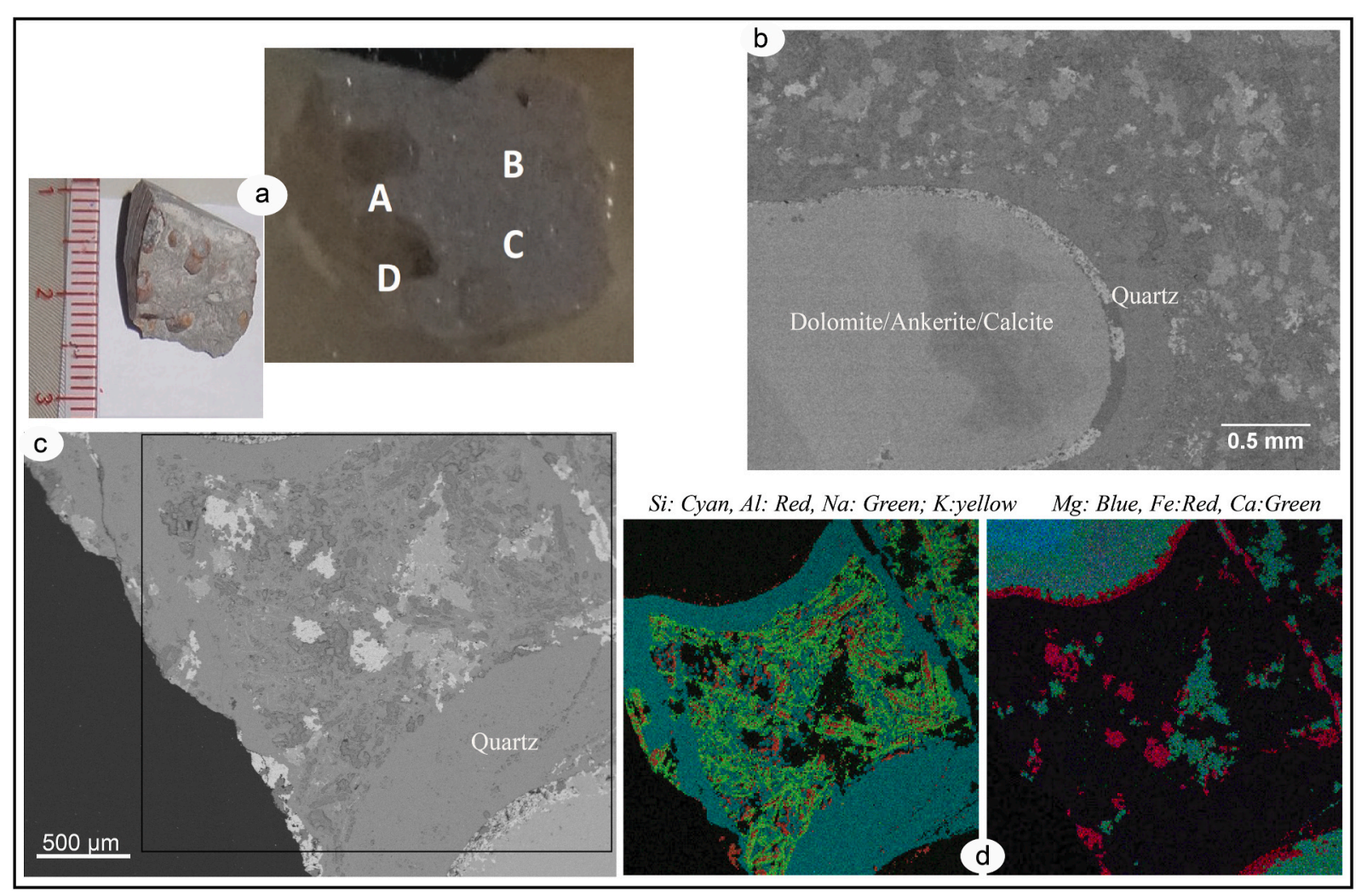

Fig. 10. Sample from $3132.46 \mathrm{~m}$ depth of the A-well. a: photo of the core fragment and the embedded polished sample. b: BSE micrograph showing a carbonate spherulite (dolomite, ankerite, and calcite with quartz rim. c: BSE micrograph of matrix between two carbonate spheroids and quartz rim. d: Composite elemental distribution maps. 


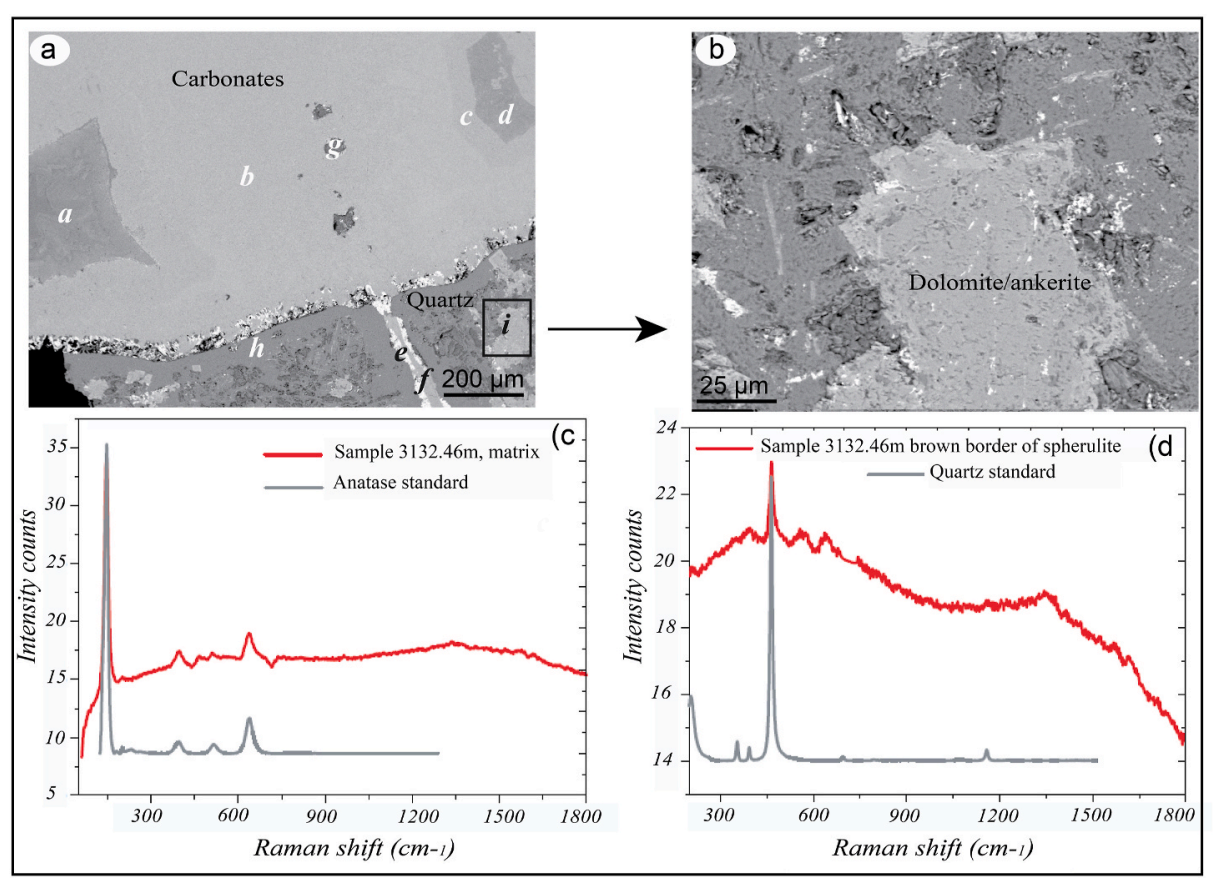

Fig. 11. Sample $3132.46 \mathrm{~m}$. a: BSE image showing fraction of a spherulite, rim, and matrix. The upper area is composed of carbonates (points a, b, c, d, e, f) with varying amounts of $\mathrm{Ca}, \mathrm{Mg}$, and $\mathrm{Fe}$ (calcite, dolomite, ankerite). $\mathbf{b}$ : higher magnification of region (i) shows the simultaneous presence of the dolomite/ankerite and titanium oxide which is distributed as fine needles in the carbonate grain. point (g) is kaolinite, point (h) quartz. c: MicroRaman spectrum, showing that $\mathrm{TiO}_{2}$ is anatase. $\mathbf{d}$ : Micro-Raman spectrum, showing that the rim is quartz.
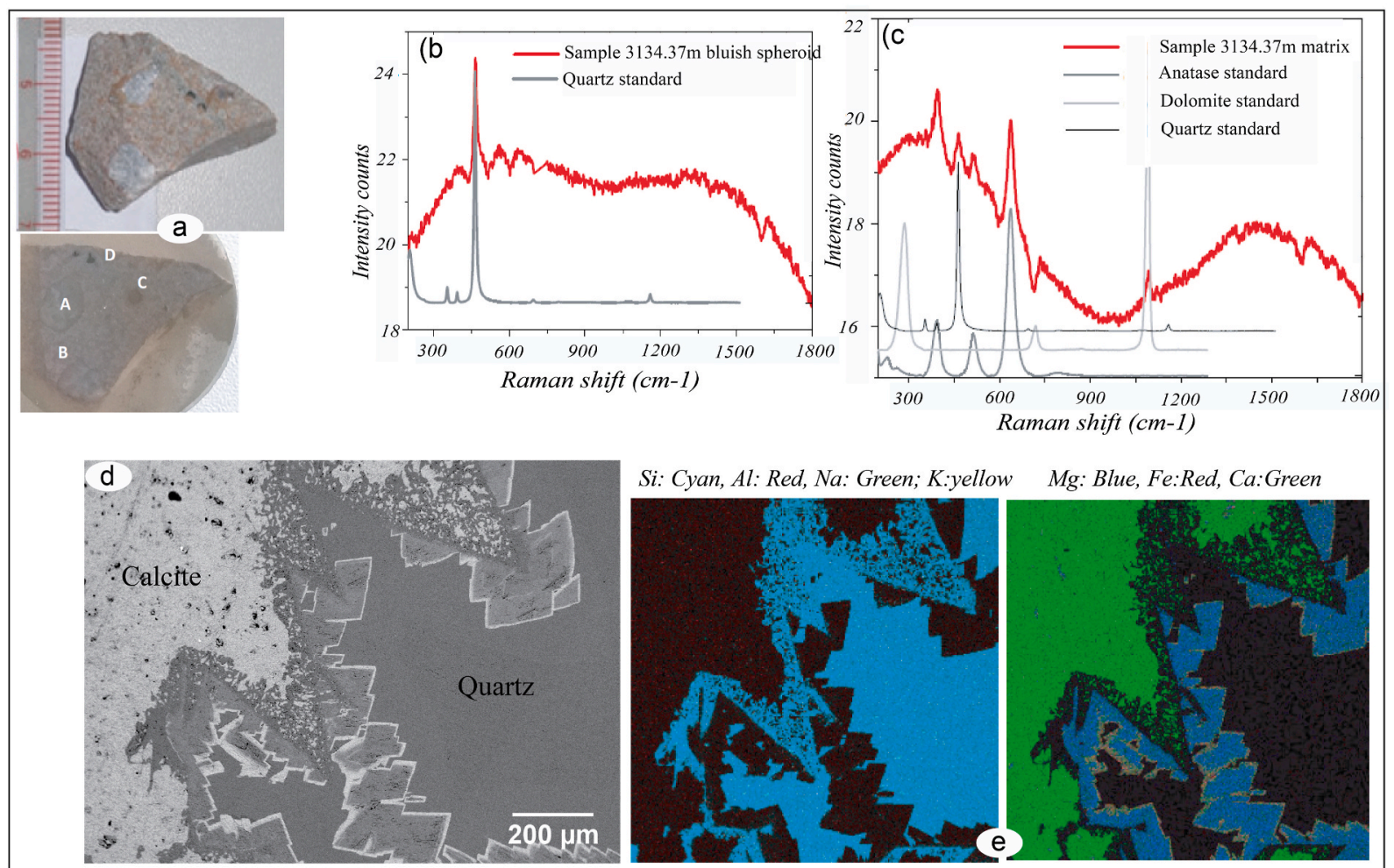

Si: Cyan, Al: Red, Na: Green; K:yellow Mg: Blue, Fe:Red, Ca:Green

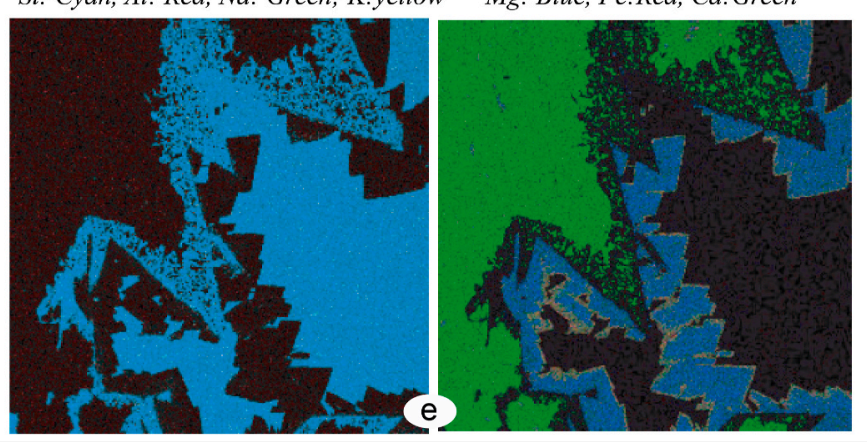

Fig. 12. Sample from a depth of $3134.37 \mathrm{~m}$. a: Photo of the rock fragment and the embedded and polished sample. b: Raman spectrum of the bluish spherulite. c: Raman spectrum of the matrix between the spherulites. d: BEI micrograph of an interface in the spherulite where quartz is replacing calcite. e: Composite element distribution maps.

Fig. 10a) indicates a polycrystalline matrix of mixed carbonates and silicate grains. The micro-Raman results are presented together with the EDX maps on the sample's regions that are identified on the microphotographs (Fig. 11a and b). Needles of $\mathrm{TiO}_{2}$ are noted in the lower right region of the amygdule, which were identified as anatase, while $\mathrm{SiO}_{2}$ from the rim was identified as quartz by micro-Raman spectra
(Fig. 11c and d).

Quartz replacement of dissolved calcite in spherulites is demonstrated by Raman spectra and by the BSE images of the bluish spheroid (8 mm) (region "A") for the sample $3134.37 \mathrm{~m}$ (Fig. 12a, b, c, d, e). BSE image and composite element distribution maps (Fig. 13a and b) demonstrate the texture of the matrix between the spherical calcite/ 


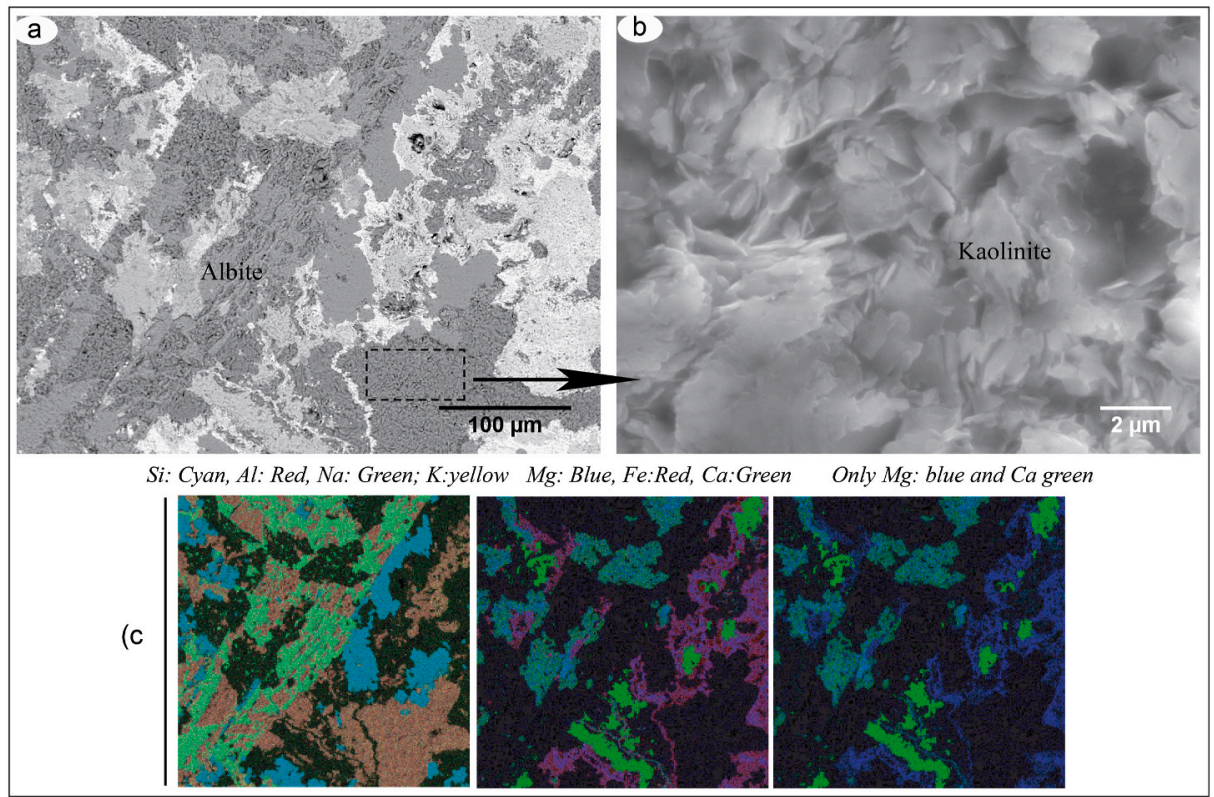

Fig. 13. Sample from a depth of $3134.37 \mathrm{~m}$ : a: BEI micrograph showing region "C" (Fig. 10a), the boundary of a spherical quartz grain with a diameter of approximately $2 \mathrm{~mm}$, strewn with dolomite grains $(10 \mu \mathrm{m}-50 \mu \mathrm{m})$ and ankerite grains $(100 \mu \mathrm{m}-200 \mu \mathrm{m})$ on the perimeter. b: Composite elemental distribution maps.

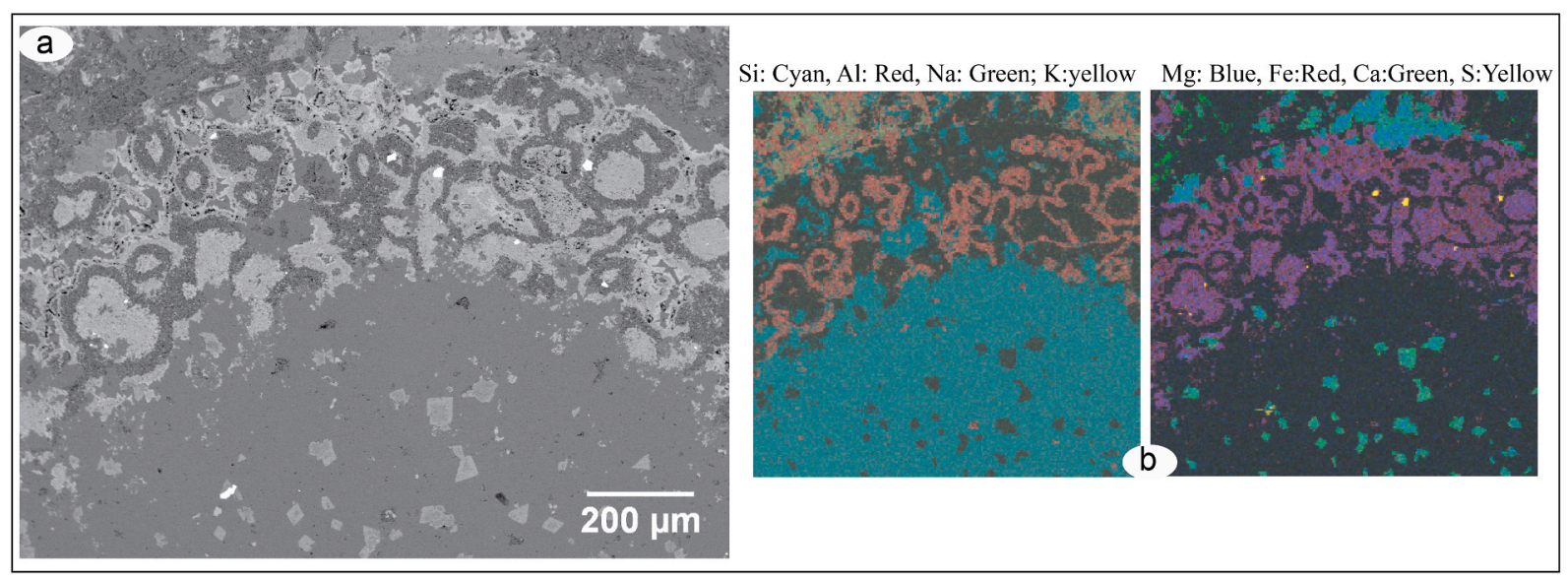

Fig. 14. Sample from the depth of $3134.37 \mathrm{~m}$. a: BSE image of the matrix between the carbonate/quartz spheroids, showing a mixture of carbonates and silicates. b: SE image at higher magnification indicated with a black arrow in (a) showing kaolinite. c: Composite elemental distribution maps: the first one emphasizes the silicates, the other two showing the carbonates. The last one, where only Mg (blue) and Ca (green) are overlaid, shows that the calcium is either present in pure calcite (green) or in dolomite (few and small grains that are cyan = blue + green). The grains that remained blue (with no Ca), when overlaid with iron, turn purple, implying that they are ankerite.

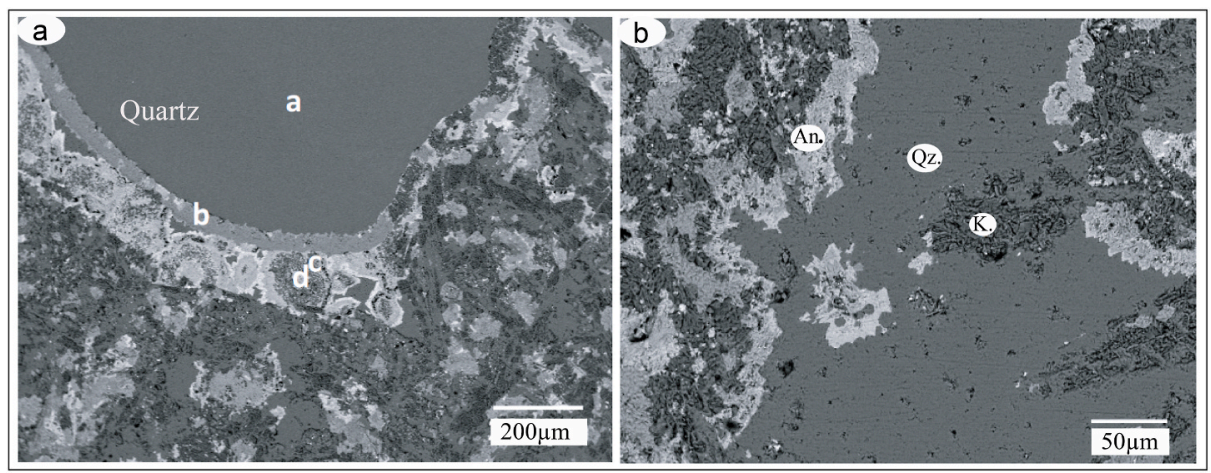

Fig. 15. Sample at $3134.37 \mathrm{~m}$ depth from the A-well: a: BSE image of the border of a $1 \mathrm{~mm}$ quartz grain showing the different parts (a, b, c, d) of the spherulite. b: BSE image with identification of the minerals of main areas; An. = Ankerite; Qz. = Quartz; K. = Kaolinite. 


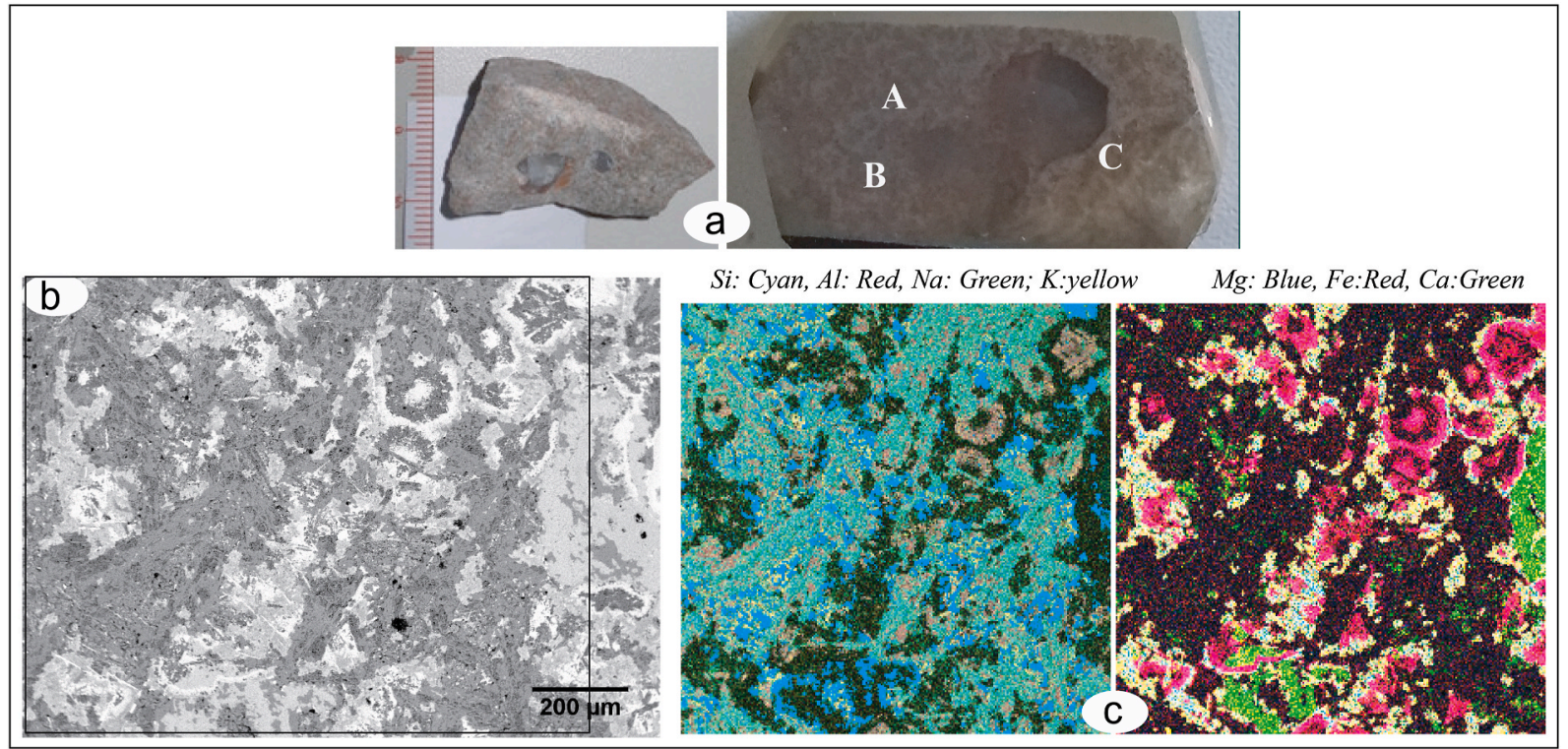

Fig. 16. Sample from a depth of ( $3135.64 \mathrm{~m})$ : A: Photo of the core fragment and the polished sample. B: BSE image showing the carbonates and silicates of the matrix (in region "A" indicated on the polished surface). C: Composite elemental distribution maps.

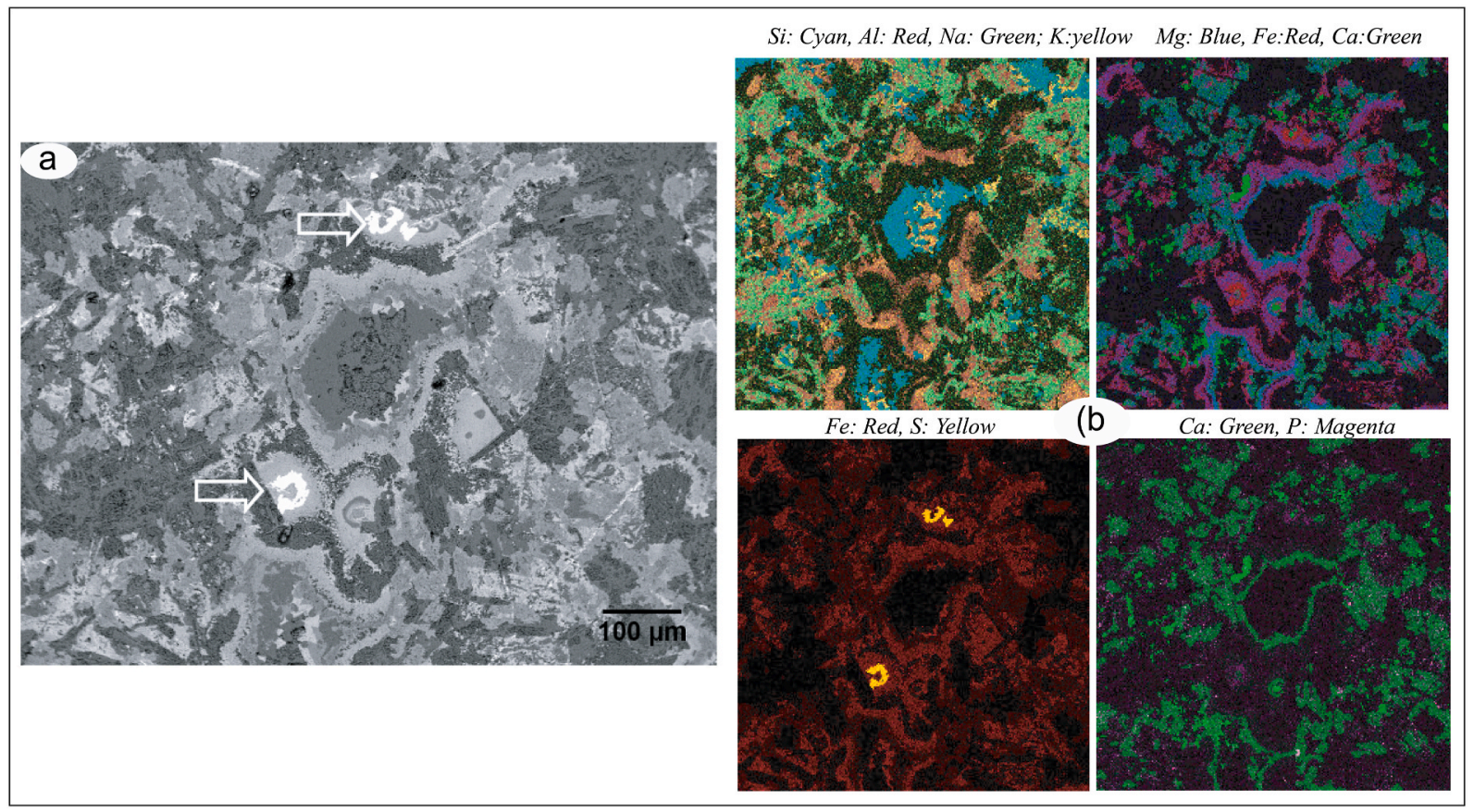

Fig. 17. Sample from $3135.64 \mathrm{~m}$ depth. a: BSE image, a region of the matrix containing pyrite (indicated with arrows). b: Composite elemental distribution maps. Fe $+\mathrm{S}$ show pyrite. $\mathrm{Ca}+\mathrm{P}$ shows apatite as pinkish dots (better discriminated in the individual P map. C: Individual element distribution EDX maps.

quartz grains and show a mixture of carbonates and silicates. Based on the texture relationship, kaolinite is replacing feldspars (Albite) that presents dissolution features as shown in Fig. 14a. The "pitted areas" (indicated by an arrow) contain only $\mathrm{Si}$ and $\mathrm{Al}$ oxides and were identified as kaolinite, confirmed by their platy morphology in the SE image (Fig. 14b). Calcium is either present in pure calcite or dolomite (few small grains). The ankerite grains contain only $\mathrm{Mg}$ and $\mathrm{Fe}$ (Ca). BSE images and element maps show the details of the quartz spheroid border (Fig. 15) with a diameter of approximately $2 \mathrm{~mm}$ from the $3134.37 \mathrm{Fm}$. The perimeter of these quartz grains (Fig. 15a) is strewn with dolomite grains (10-50 $\mu \mathrm{m}$ diameter) and with $100-200 \mu \mathrm{m}$ ankerite grains (Fig. 15b) enveloped in alumino-silicates, where pyrite grains can be found as well. Other forms of hydrothermal alteration are illustrated with BSE image and composite, individual element distribution maps. These new forms prove the existence of a mixture of mineralization for the sample $3135.64 \mathrm{~m}$, as myrmekitic quartz, pyrite, and iron-rich ankerite vesicles (Fig. 16) and anatase needles. Iron-rich carbonates envelop the pyrite as shown in Fig. 17a and b.

\subsection{Petrophysical properties of the doleritic intrusion}

Laboratory measurements of helium porosity and air permeability were used to evaluate the petro-physical properties of the magmatic intrusion. The evolution of permeability and porosity with depth in the 

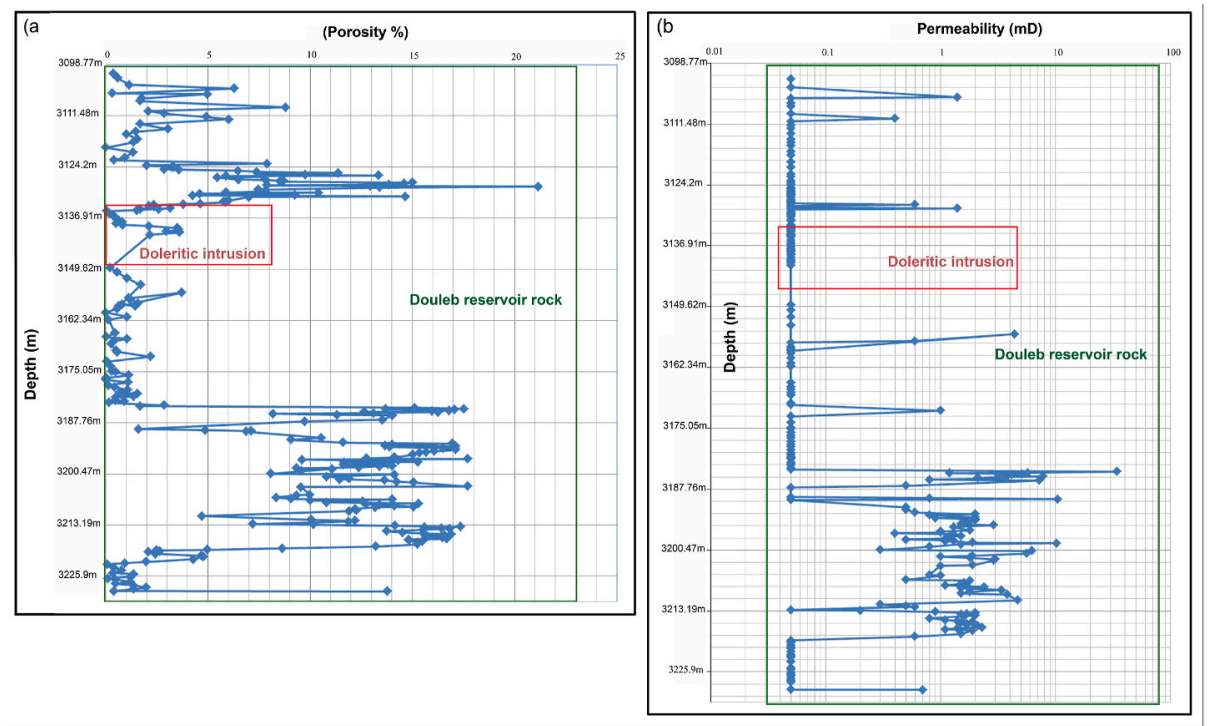

Fig. 18. Variation of the porosity (18a) and permeability (18 b) with depth in the Douleb formation and the doleritic intrusion.

Table. 3a

Permeability and porosity measurements in the Douleb reservoir (A-well).

\begin{tabular}{ll}
\hline Depth $(\mathrm{m})$ & Permeability (mD) \\
\hline $3098.77-3176.75$ & $0.1-4.4$ (mean permeability) \\
$3176.75-3207.63$ & $0.05-10-30.2$ (mean to good permeability) \\
$3207.63-3217.74$ & 0.1 (low permeability) \\
\hline
\end{tabular}

\section{Table 3b}

Permeability and porosity measurements in the Douleb reservoir (A-well).

\begin{tabular}{ll}
\hline Depth $(\mathrm{m})$ & Porosity (\%) \\
\hline $3100.96-3126.86$ & $0.0-8.0$ (mean porosity) \\
$3126.86-3132.94$ & $1-21$ (good porosity) \\
$3132.94-3176.75$ & $0.0-5$ (mean porosity) \\
$3176.75-3207.14$ & $5-18$ (good porosity) \\
$3207.14-3217.74$ & $0.0-5$ (mean porosity) \\
\hline
\end{tabular}

A-well core is presented in Fig. 18 (a, b) and Table 3. The magmatic intrusion $(3141.23 \mathrm{~m}-3131.51 \mathrm{~m})$ is characterized by zero core porosity $(0.0 \%)$ and a maximum of $15.0 \%$ with mean permeability of ${ }^{<} 0.1 \mathrm{mD}$.

\section{Discussion}

The complexity of structuring in the Gabes Gulf and especially in the MX area is related to Tethyan rifting that caused a crustal thinning. This thinned crust was a favorable zone for the establishment of magmatism and hydrothermalism. This hydrothermal alteration caused a variation in the mineral paragenesis of the doleritic intrusion and modifications in its petrophysical properties.

\subsection{Mineral transformation in the doleritic intrusion}

The availability of the core samples in the doleritic intrusion made the Douleb reservoir rock in the A-well an ideal case to prove the impact of the hydrothermal fluids. There is a decrease in the transformation degree with depth (Fig. 7). Brittle deformation dominates in the doleritic intrusion of the A-well as shown by the fracturing of primary minerals like plagioclase, olivine, and clinopyroxene grains. Producing a progressive grain size reduction and allowing fluids to penetrate the rock, which enhanced the formation of hydrated minerals (Gerald and Stünitz, 1993). No features of plagioclase or clinopyroxene recrystallization have been identified in this doleritic intrusion. This absence has been ascribed to fluid-assisted deformation (Bonatti et al., 1975; Helmstaedt and Allen, 1977; Mevel, 1984; Essaifi et al., 1995; Kamel et al., 1996; Martin et al., 2003). In the intracrystalline fractures of plagioclase, sericite and clay minerals are predominant. They are formed as well in the matrix, at the expense of clinopyroxene. SEM/EDX studies showed that the plagioclase is predominantly albite. Many authors (e.g., Moody et al., 1983; Mas et al., 2006) confirmed the albite formation in a hydrothermal context. Fluid/rock interaction process and percolation of heated seawater in the pile of the Cretaceous doleritic intrusion resulted in precipitation of hydrothermal minerals filling the amygdules $(0.2 \mathrm{~mm}-7 \mathrm{~mm}$ in size), cooling of related veins and veinlets of $0.1 \mathrm{~mm}-1 \mathrm{~mm}$ thickness. The spherulites are generally filled with quartz and dolomite/ankerite or calcite. The doleritic intrusion presents different types of amygdule with a variable mineralization:

- Amygdule (appear blue macroscopically) consistent with carbonate (dolomite or calcite or ankerite-corresponding to the central area) (Figs. 10b and 11a) with non-crystalline iron and quartz in the rim. - Amygdule showing an interface where silica is replacing calcite (Fig. 12b).

- Amygdule with quartz in the core with a diameter of approximately $2 \mathrm{~mm}$, mixed with some carbonate grains. The borders of these filled vesicles are strewn with $10 \mu \mathrm{m}-50 \mu \mathrm{m}$ dolomite, and with 100 $\mu \mathrm{m}-200 \mu \mathrm{m}$ ankerite grains (Fig. 15a).

The matrix between the spherical carbonates/quartz grains shows a mixture of carbonates, silicates such as calcite, dolomite, ankerite, quartz, and albite, and phyllosilicates such as kaolinite (Fig. 14a and b). Authigenic phyllosilicates are commonly described in submarine hydrothermal systems (McMurtry and Yeh, 1981; Eric et al., 1983; Honnorez, 1983; McMurtry et al., 1983; Murnane and Clague, 1983; Alt et al., 1986, 2010; Alt, 1988; STOFFERS et al., 1990; Alt and Jiang, 1991; Lackschewitz et al., 2000; Marteinsson et al., 2001; Geptner et al., 2002). The clay minerals observed in the doleritic intrusion are composed of kaolinite and chlorite. SEM observations revealed hexagonal platelets of kaolinite. The chlorite typically shows a grey-brown to dark green birefringence under crossed polar, which is indicative of a Fe-rich composition (Teboul et al., 2017). Kaolinite seems to be formed by replacing feldspars and in the case of chlorite, it is probably formed through direct precipitation in veins. Several authors have described the chlorite formation in hydrothermal environments as a result of 


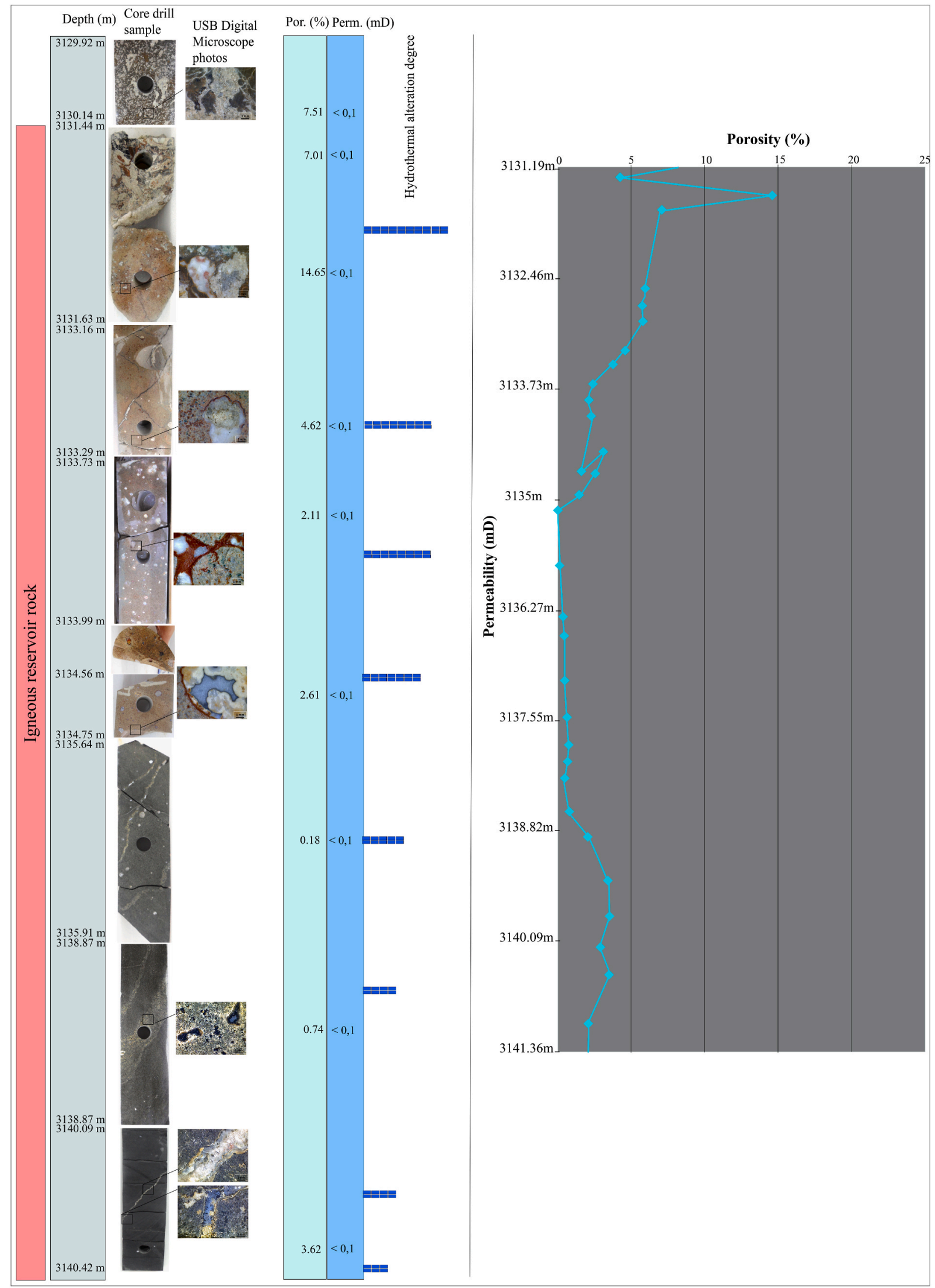

Fig. 19. Representation showing the relationship between the modification of the petrography (USB Digital Microscope), the hydrothermal alteration degree, and the petrophysical parameters. 
fluid-rock interaction (Burton et al., 1987; Drief et al., 2001; Mas et al., 2006; Abd Elmola et al., 2017). In our case study, the carbonate formation observed in the doleritic intrusion is related to hydrothermal activity. The source of $\mathrm{Mg}$ and $\mathrm{Ca}$ can be related to the dissolution of limestones in the Douleb Formation as a result of fluid/rock interaction. These findings are in agreement with the results of many other studies (e.g., Alt et al., 1986; Alt, 1988; Laverne et al., 1989; Gysi and Stefánsson, 2012). The absence of Raman bands at $1700 \mathrm{~cm}^{-1}$ confirms the non-biological origin of dolomite found in the samples. According to Sun et al. (2014), the changes in the Mg content in carbonates caused a red shift and peak broadening of the $\mathrm{v}_{1}$ symmetric $\left(\mathrm{CO}_{3}\right)_{2}$ stretching, which is in agreement with the results obtained in the $3135.64 \mathrm{~m}$ sample. Anatase was found in the doleritic intrusion forming fine needles, distributed among the other minerals from the matrix. The presence of ankerite grains could be related to the cooling of volcanic $\mathrm{CO}_{2}$-rich hydrothermal fluids (Teboul et al., 2017). The occurrence of the siderite crystals is an example of a chemical microenvironment and is an illustration of the heterogeneity of the alteration effects. Even though anatase is thermodynamically always unstable concerning rutile (Shannon and Pask, 1965; Hanaor and Sorrell, 2011 and references therein), in this case, the observed polymorph was always anatase. The formation of anatase under hydrothermal conditions should be regarded as a consequence of sluggish reaction kinetics or metastable crystallization (Rao, 1961; Shannon and Pask, 1965; Black and Hynek, 2018). Disseminated pyrite and apatite were also found in the studied dolerite, which showed a mineralogical zonation in the concentric envelopes of the spherulites. This zonation indicates a fluctuation of the chemical composition of the hydrothermal fluid during the alteration. The presence of myrmekite in the studied microdoleritic intrusion may be related to the hydrothermal circulations and the fractionation of plagioclase crystals. Putnis and Austrheim (2013) proved that both micro-fractured plagioclase and the full of connected pores through which fluids can move in and out of the crystals are favorable conditions for myrmekite formation. In recrystallized and metasomatically altered rocks, myrmekite has been found at several localities (Collins, 1998; Collins and Collins, 2002; Tsurumi et al., 2003; Yuguchi and Nishiyama, 2008).

\subsection{Hydrothermal fluids impact on the physical properties of the doleritic intrusion}

Recently, the igneous reservoir rocks attracted the attention of several authors from all over the world (Petford, 2003; Wu et al., 2006; Delpino and Bermúdez, 2009; Zou, 2013; Sydnes et al., 2018; Spacapan et al., 2020). The quantitative characterization of the porosity and the permeability gives more information that can help in reducing the uncertainties about this reservoir rock. The porosity of igneous reservoirs can be divided into primary and secondary (Petford, 2003; Bermúdez and Delpino, 2008; Zou, 2013). Primary porosity refers to the pores and fractures generated during magma intrusion, cooling, and crystallization. It includes vesicles, intercrystalline pores (Feng et al., 2008; Zou, 2013), and cooling fractures (Bermúdez and Delpino, 2008). Secondary porosity includes all the pores generated by tectonic stress and dissolution processes. Secondary fracture porosity is mainly related to tectonic events and hydrothermal alteration processes (Bermúdez and Delpino, 2008). In the present study, the porosity, and the permeability of the doleritic intrusion are closely related to their petrography, which is affected in turn by the hydrothermal alteration. The mineralogical and petrographical studies of the doleritic intrusion in the A-well show improvement of the porosity with increasing degree of hydrothermal alteration (Fig. 19). Furthermore, the intensification of this transformation is accompanied by the development of new minerals, abundance of pores and spherulites. Hydrothermal veins resulting from pressure build-up in the contact act as channels for hydrocarbons migration, connecting deep source rocks to shallow magmatic reservoir. Calcite and/or quartz are very abundant in fracture, pores, micro-pores and as spherulites fillings. They have a significant impact in the quality

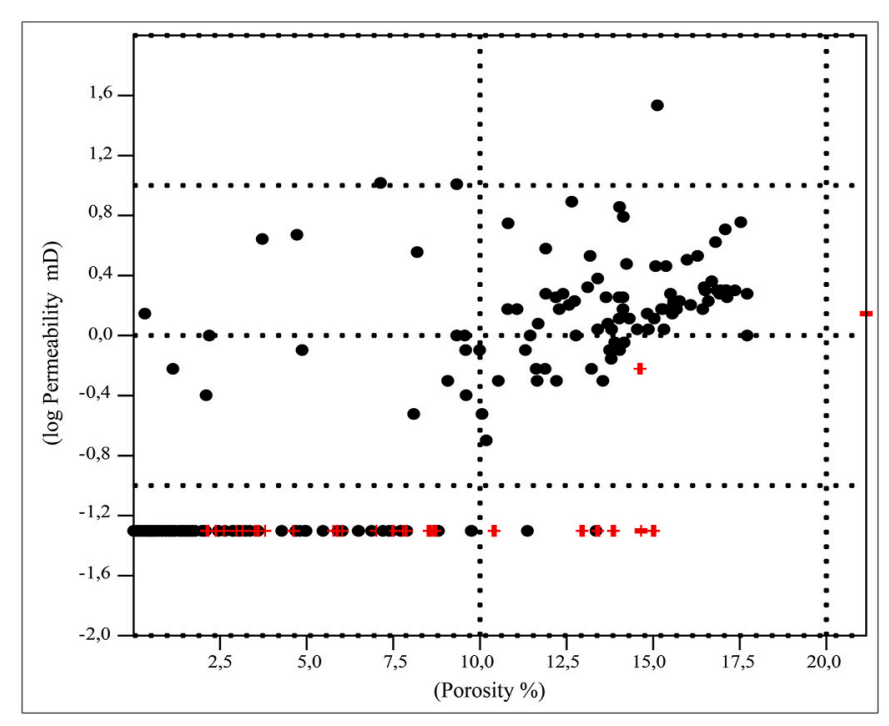

Fig. 20. Comparison diagram of porosity and the permeability of the Douleb formation (A-well) presented by black points and the doleritic intrusion (Red Cross).

of altered doleritic intrusion porosity, whereas the primary minerals (plagioclases and clinopyroxenes) define primary porosity and characterized by low porosity. Throughout this doleritic intrusion, the porosity has an average value, but the permeability is constant (0.1mD) (Fig. 20), this low value is due to the lack of connection between the pores, the spherulites and the fractures. Furthermore, the dissolution of the primary crystals created secondary pores and spherulites that are partially occluded by the precipitation of calcite, ankerite and quartz, often leaving a remainder of new pore spaces. Additionally, some USB digital photos of the core and petrographic thin sections show that, in some cases, secondary quartz and calcite may occlude the fracture porosity. Based on that, the porosity and permeability have a close relationship with the precipitation of secondary minerals and the connection between pores, spherulites and fractures. This work reveals the strong impact of magmatism-hydrothermalism in the magmatic intrusion petro-physical properties that can be considered one of the key parameters controlling the potentiality of hydrocarbon during the petroleum investigation. It is worth mentioning that not only hydrothermal activity has improved the reservoir porosity but also the tectonic activity in the area played a role by forming several fractures and microfractures within the rock.

\section{Conclusions}

The results of the present study show that the doleritic intrusion (Gabes Gulf) has been affected by several stages of hydrothermal circulation that affected both the mineralogy and the petro-physical properties. The initial mineralogical composition composed of olivine, clinopyroxene, and plagioclase was modified by dissolutionprecipitation mechanism and direct mineral formation within fractures and veins. This is marked by the destruction of the primary plagioclase, silicification, clay mineral crystallization, sericitization, and carbonate formation. The variation of the alteration products is probably related to changes in the chemical composition of the hydrothermal fluids. The increase of the hydrothermal alteration degree is accompanied by the improvement of the porosity as a result of the dissolution process that increased the pores and micropores. However, the new mineralization within the fractures and micro-fractures has reduced the doleritic intrusion permeability. The results of the present study highlight the important role of hydrothermal activity on the petro-physical properties of magmatic intrusions that may result in hydrocarbons trapping (accumulation). Moreover, the results opened the door for 
further investigations to check the potential presence of hydrocarbons within the doleritic intrusion.

\section{Declaration of competing interest}

The authors declare that they have no known competing financial interests or personal relationships that could have appeared to influence the work reported in this paper.

\section{Acknowledgment}

The author would like to thank the Tunisian Enterprise of Petroleum Activity (ETAP) and the University of Sciences Tunis El Manar for supporting this research. Also, a special thanks to the Laboratório de Microanálise, Universidade Federal do Rio Grande do Sul, Porto Alegre, RS, (Brazil) for micro-Raman spectrometry and EM/EDX analysis. The authors gratefully acknowledge the Ontario Cluster of Excellence (OCE) for the Talent Edge Funding at York University.

\section{References}

Abd Elmola, A., Charpentier, D., Buatier, M., Lanari, P., Monié, P., 2017. Texturalchemical changes and deformation conditions registered by phyllosilicates in a fault zone (Pic de Port Vieux thrust, Pyrenees). Appl. Clay Sci. 144, 88-103. https://doi. org/10.1016/j.clay.2017.05.008.

Alt, J.C., 1988. Hydrothermal oxide and nontronite deposits on seamounts in the eastern Pacific. Mar. Geol. 81, 227-239.

Alt, J.C., Honnorez, J., Laverne, C., Emmermann, R., 1986. Hydrothermal alteration of a $1 \mathrm{~km}$ section through the upper oceanic crust, Deep Sea Drilling Project Hole 504B: mineralogy, chemistry and evolution of seawater-basalt interactions. J. Geophys. Res.: Solid Earth 91, 10309-10335.

Alt, J.C., Jiang, W.-T., 1991. Hydrothermally precipitated mixed-layer illite-smectite in recent massive sulfide deposits from the sea floor. Geology 19, 570-573.

Alt, J.C., Laverne, C., Coggon, R.M., Teagle, D.A., Banerjee, N.R., Morgan, S., SmithDuque, C.E., Harris, M., Galli, L., 2010. Subsurface structure of a submarine hydrothermal system in ocean crust formed at the East Pacific Rise, ODP/IODP Site 1256. G-cubed 11.

Balachandran, U., Eror, N.G., 1982. Raman spectra of titanium dioxide. J. Solid State Chem. 42, 276-282.

Bédir, M., 1995. Mécanismes géodynamiques des bassins associés aux couloirs de coulissements de la marge atlasique de la Tunisie: Séismo-stratigraphie, séismotectonique et implications pétrolières ( $\mathrm{PhD}$ Thesis).

Bedir, M., Zargouni, F., Tlig, S., Bobier, C., 1992. Subsurface geodynamics and petroleum geology of transform margin basins in the Sahel of Mahdia and El Jem (eastern Tunisia)(1). AAPG Bull. 76, 1417-1442.

Ben Ferjani, A., Burollet, P.F., Mejri, F., 2006. Petroleum geology of Tunisia. A Renewed Synthesis. Mem ETAP., 229p.

Ben Saleh, A., 2015. Magmatisme crétacé-hydrothermalisme de la partie Nord-Est du Golfe : Impact sur le système pétrolier (Master). Tunis, Tunisia.

Bermúdez, A., Delpino, D.H., 2008. Concentric and radial joint systems within basic sills and their associated porosity enhancement, Neuquén Basin, Argentina. Geol. Soc. Lond. Spec. Publ. 302, 185-198.

Black, S.R., Hynek, B.M., 2018. Characterization of terrestrial hydrothermal alteration products with Mars analog instrumentation: implications for current and future rover investigations. Icarus 307, 235-259.

Bonatti, E., Honnorez, J., Kirst, P., Radicati, F., 1975. Metagabbros from the Mid-Atlantic Ridge at $06^{\circ} \mathrm{N}$ : contact-hydrothermal-dynamic metamorphism beneath the axial valley. J. Geol. 83, 61-78.

Bouaziz, S., Barrier, E., Soussi, M., Turki, M.M., Zouari, H., 2002. Tectonic evolution of the northern African margin in Tunisia from paleostress data and sedimentary record. Tectonophysics 357, 227-253.

Boughdiri, M., Cordey, F., Sallouhi, H., Maâlaoui, K., Masrouhi, A., Soussi, M., 2007. Jurassic radiolarian-bearing series of Tunisia: biostratigraphy and significance to western Tethys correlations. Swiss J. Geosci. 100, 431-441.

Buness, H., Giese, P., Bobier, C., Eva, C., Merlanti, F., Pedone, R., Jenatton, L., Nguyen, D.T., Thouvenot, F., Egloff, F., 1992. The EGT-85 Seismic Experiment in Tunisia-a reconnaissance of the deep structures. Tectonophysics 207, 245-267.

Burton, J.H., Krinsley, D.H., Pye, K., 1987. Authigenesis of kaolinite and chlorite in Texas Gulf Coast sediments. Clay Clay Miner. 35, 291-296.

Buzgar, N., Apopei, A.I., Buzatu, A., 2009. Romanian Database of Raman Spectroscopy. Castany, G., 1954. Laccident sud-tunisien, son age et ses relations avec laccident SudAtlasique Dalgerie. Comptes Rendus Hebd. Seances Acad. Sci. 238, 916-918.

Chemarin, C., Panczer, G., Badjukov, D.D., Champagnon, B., 1996. Progressive transformation from quartz to amorphous silica by shock pressure: role of the $\alpha \rightarrow \beta$ transition. Ber. Bunsen Ges. Phys. Chem. 100, 1396-1398.

Collins, L.G., 1998. Metasomatic Origin of the Cooma Complex in Southeastern Australia.

Collins, L.G., Collins, B.J., 2002. Myrmekite Formation at Temecula, California, Revisited: A Photomicrographic Essay Illustrating Replacement Textures.
Cook, S.E., Wright, V.P., 1998. The miskar gas condensate field. In: Presented at the Proceeding of the 6th Tunisian Petroleum Exploration and Production Conference. Tunis, pp. 97-109.

de Lamotte, D.F., Leturmy, P., Missenard, Y., Khomsi, S., Ruiz, G., Saddiqi, O., Guillocheau, F., Michard, A., 2009. Mesozoic and Cenozoic vertical movements in the Atlas system (Algeria, Morocco, Tunisia): an overview. Tectonophysics 475, 9-28.

Delpino, D.H., Bermúdez, A.M., 2009. Petroleum systems including unconventional reservoirs in intrusive igneous rocks (sills and laccoliths). Lead. Edge 28, 804-811.

Dercourt, J., Zonenshain, L.P., Ricou, L.-E., Kazmin, V.G., Le Pichon, X., Knipper, A.L., Grandjacquet, C., Sbortshikov, I.M., Geyssant, J., Lepvrier, C., 1986. Geological evolution of the Tethys belt from the Atlantic to the Pamirs since the Lias. Tectonophysics 123, 241-315.

Dey, Z., Saidi, M., Inoubli, H., Ben Kilani, H., 2002. Basin Modelling of the Gulf of Gabes, Structural Evolution and Hydrocarbon Potentiel. ETAP.

Dkhaili, N., Bey, S., El Abed, M., Gasmi, M., Inoubli, M.H., 2015. Integrated geophysical and geological study and petroleum appraisal of Cretaceous plays in the Western Gulf of Gabes, Tunisia. Tectonophysics 658, 1-13. https://doi.org/10.1016/j. tecto.2015.06.033.

Downs, B., Robinson, S., Yang, H., Mooney, P., 2015. RRUFF Project. Dep. Geosci. Univ, Arizona.

Drief, A., Nieto, F., Sanchez-Navas, A., 2001. Experimental clay-mineral formation from a subvolcanic rock by interaction with $1 \mathrm{M} \mathrm{NaOH}$ solution at room temperature. Clay Clay Miner. 49, 92-106.

Eric, H., McMurtry, G.M., Yeh, H.-W., 1983. Geochemistry of hydrothermal deposits from Loihi submarine volcano, Hawaii. Earth Planet Sci. Lett. 66, 438-449.

Essaifi, A., Capdevila, R., Lagarde, J.-L., 1995. Transformation de leucogabbros en chloritoschistes sous l'effet de l'altération hydrothermale. C. R. Acad. Sci. Earth Planet. Sci. Sci. Terre Planèt. Sér. II 320, 189.

ETAP, 2006. Petroleum geology of Tunisia. A renewed synthesis.

Feng, Z.H., Shao, H.M., Tong, Y., 2008. Controlling factors of volcanic gas reservoir property in Qingshen gas field, Songliao basin. Acta Geol. Sin. 82, 760-768.

Frizon de Lamotte, D., Raulin, C., Mouchot, N., Wrobel-Daveau, J.-C., Blanpied, C., Ringenbach, J.-C., 2011. The southernmost margin of the Tethys realm during the Mesozoic and Cenozoic: initial geometry and timing of the inversion processes. Tectonics 30 .

Gabtni, H., Zenatti, B.C., Jallouli, C., Mickus, K.L., Bedir, M., 2011. The crustal structure of the Sahel Basin (eastern Tunisia) determined from gravity and geothermal gradients: implications for petroleum exploration. Arab. J. Geosci. 4, 507-516.

Geptner, A., Kristmannsdottir, H., Kristjansson, J., Marteinsson, V., 2002. Biogenic saponite from an active submarine hot spring, Iceland. Clays Clay Min. 50, 174-185.

Gerald, J.F., Stünitz, H., 1993. Deformation of granitoids at low metamorphic grade. I: reactions and grain size reduction. Tectonophysics 221, 269-297.

Guiraud, R., 1998. Mesozoic rifting and basin inversion along the northern African Tethyan margin: an overview. Geol. Soc. Lond. Spec. Publ. 132, 217-229.

Guiraud, R., Maurin, J.-C., 1992. Early cretaceous rifts of western and central Africa: an overview. Tectonophysics 213, 153-168.

Gysi, A.P., Stefánsson, A., 2012. Mineralogical aspects of CO2 sequestration during hydrothermal basalt alteration - an experimental study at 75 to $250 \mathrm{C}$ and elevated pCO2. Chem. Geol. 306, 146-159.

Hanaor, D.A.H., Sorrell, C.C., 2011. Review of the anatase to rutile phase transformation. J. Mater. Sci. 46, 855-874. https://doi.org/10.1007/s10853-010-5113-0.

Hedenquist, J.W., Lowenstern, J.B., 1994. The role of magmas in the formation of hydrothermal ore deposits. Nature 370, 519-527.

Helmstaedt, H., Allen, J.M., 1977. Metagabbronorite from DSDP hole 334: an example of high-temperature deformation and recrystallization near the Mid-Atlantic Ridge. Can. J. Earth Sci. 14, 886-898.

Honnorez, J., 1983. Sedimentology, Mineralogy and Geochemistry of Green Clay Samples from the Galapagos Hydrothermal Mounds, Haloes 506, 506C, and 507D, Deep Sea Drilling Project leg 70 (preliminary data). Init. Rept. DSDP, vol. 70, pp. 221-224.

Kamel, S., Bouabid, R., Boulange, B., Colin, F., 1996. Hydrothermal and supergene Paléoaltération of triasic basalt of the middle Atlas, Morocco. Newspap. Afr. Earth Sci. 2, 225-235.

Khomsi, S., Echihi, O., Slimani, N., 2012. Structural control on the deep hydrogeological and geothermal aquifers related to the fractured Campanian-Miocene reservoirs of north-eastern Tunisia foreland constrained by subsurface data. Compt. Rendus Geosci. 344, 247-265.

Lackschewitz, K.S., Singer, A., Botz, R., Garbe-Schonberg, D., Stoffers, P., Horz, K., 2000. formation and transformation of clay minerals in the hydrothermal deposits of middle valley, Juan de Fuca ridge, ODP leg 169. Econ. Geol. 95, 361-389.

Laridhi Ouazaa, N., Bédir, M., 2004. Les migrations tectono-magmatiques du Trias au Miocène sur la marge orientale de la Tunisie. Afr. Geosci. Rev. 11, 177-194.

Laridhi-Ouazaa, N., 1994. Etude minéralogique et géologique des épisodes magmatiques mésozoïques et miocènes de la Tunisie. Université de Tunis II. Thèse d'Etat, p. 466.

Laverne, C., Honnorez, J., Alt, J., 1989. Transition entre l'alteration a basse temperature et l'alteration hydrothermale de la croute oceanique; etude petrographique et geochimique du puits 504B, Est Pacifique. Bull. Soc. Geol. Fr. 327-337.

Lowell, R.P., Rona, P.A., Von Herzen, R.P., 1995. Seafloor hydrothermal systems. J. Geophys. Res.: Solid Earth 100, 327-352.

Marteinsson, V.T., Kristjánsson, J.K., Kristmannsdóttir, H., Dahlkvist, M., Sæmundsson, K., Hannington, M., Pétursdóttir, S.K., Geptner, A., Stoffers, P., 2001. Discovery and description of giant submarine smectite cones on the seafloor in Eyjafjordur, northern Iceland, and a novel thermal microbial habitat. Appl. Environ. Microbiol. 67, 827-833. 
Martin, U., Reischmann, T., Bahlburg, H., Schätz, M., Tait, J., Bachtadse, V., 2003. The early palaeozoic break-up of northern Gondwana: sedimentology, physical volcanology and geochemistry of a submarine volcanic complex in the Bavarian facies association, Saxothuringian Basin, Germany. Gondwana Res. 6, 839-858.

Mas, A., Guisseau, D., Mas, P.P., Beaufort, D., Genter, A., Sanjuan, B., Girard, J.-P., 2006 Clay minerals related to the hydrothermal activity of the Bouillante geothermal field (Guadeloupe). J. Volcanol. Geoth. Res. 158, 380-400.

Masrouhi, A., Koyi, H.A., 2012. Submarine 'salt glacier' of Northern Tunisia, a case of Triassic salt mobility in North African Cretaceous passive margin. Geol. Soc. Lond. Spec. Publ. 363, 579-593.

Matoussi Kort, H., 2008. Les emissions magmatiques cretacées de subsurface de la marge orientale de la Tunisie: Pétrologie, géochimie, effet thermique sur l'encaissant sédimentaire et implications géodynamiques ( $\mathrm{PhD}$ Thesis). Thèse Es-Sciences. Université de Tunis II.

Matoussi Kort, H., Gasquet, D., Ikenne, M., Laridhi Ouazaa, N., 2009. Cretaceous crustal thinning in North Africa: implications for magmatic and thermal events in the eastern Tunisian margin and the Pelagic Sea. J. Afr. Earth Sci. 55, 257-264. https:// doi.org/10.1016/j.jafrearsci.2009.04.011.

Matoussi Kort, H., Mabrouk El Asmi, A., Laridhi Ouazaa, N., Gasquet, D., Saidi, M., 2015. Hydrothermal history in the eastern margin of Tunisia: inferred magmatic rocks alterations, new paragenesis and associated gas occurrences. Arab. J. Geosci. 8, 8927-8942.

Matoussi Kort, H.M., Sassi, A.B., Ouazaa, N.L., 2008. Thermal and hydrothermal influence of magmatic emissions on embedding clays of the Upper Cretaceous of the Tunisian eastern margin and the Pelagic Sea. Compt. Rendus Geosci. 340, 298-305.

McMurtry, G.M., Chung-Ho, W., Hsueh-Wen, Y., 1983. Chemical and isotopic investigations into the origin of clay minerals from the Galapagos hydrothermal mounds field. Geochem. Cosmochim. Acta 47, 475-489.

McMurtry, G.M., Yeh, H.-W., 1981. Hydrothermal clay mineral formation of east Pacific rise and Bauer basin sediments. Chem. Geol. 32, 189-205.

Mevel, C., 1984. Le métamorphisme dans la croûte océanique: apport de la pétrologie à la compréhension des phénomènes de circulation hydrothermale et de déformation (exemples dans l'Atlantique) ( $\mathrm{PhD}$ Thesis).

Moody, J.B., Meyer, D., Jenkins, J.E., 1983. Experimental characterization of the greenschist/amphibolite boundary in mafic systems. Am. J. Sci. 283, 48-92.

Murnane, R., Clague, D.A., 1983. Nontronite from a low-temperature hydrothermal system on the Juan de Fuca Ridge. Earth Planet Sci. Lett. 65, 343-352.

Naji, C., Masrouhi, A., Amri, Z., Gharbi, M., Bellier, O., 2018. Cretaceous paleomargin tilted blocks geometry in northern Tunisia: stratigraphic consideration and fault kinematic analysis. Arab. J. Geosci. 11, 583.

Patriat, M., Ellouz, N., Dey, Z., Gaulier, J.-M., Kilani, H.B., 2003. The Hammamet, Gabes and Chotts basins (Tunisia): a review of the subsidence history. Sediment. Geol. 156, 241-262.

Petford, N., 2003. Controls on primary porosity and permeability development in igneous rocks. Geol. Soc. Lond. Spec. Publ. 214, 93-107.

Philips, B.R., Beckett, D., 2000. Structure and evolution of the hasdrubal gas condensate fields: gulf of Gabes, offshore Tunisia. In: Proceeding of the 7th Tunisian Petroleum Exploration and Production Conference, pp. 349-364.

Putnis, A., Austrheim, H., 2013. Mechanisms of metasomatism and metamorphism on the local mineral scale: the role of dissolution-reprecipitation during mineral reequilibration. In: Metasomatism and the Chemical Transformation of Rock. Springer, pp. 141-170.
Rao, C.N.R., 1961. Kinetics and thermodynamics of the crystal structure transformation of spectroscopically pure anatase to rutile. Can. J. Chem. 39, 498-500.

Reservoirs Inc., 1990. Geological Analysis of Conventional Core from the British Gas Inc, Miskar-6, Miskar Field, ume 4. Golfe de Gabes, Tunisia (Internal Report).

Rividi, N., van Zuilen, M., Philippot, P., Menez, B., Godard, G., Poidatz, E., 2010. Calibration of carbonate composition using micro-Raman analysis: application to planetary surface exploration. Astrobiology 10, 293-309.

Sekiya, T., Ohta, S., Kamei, S., Hanakawa, M., Kurita, S., 2001. Raman spectroscopy and phase transition of anatase TiO2 under high pressure. J. Phys. Chem. Solid. 62, $717-721$.

Shannon, R.D., Pask, J.A., 1965. Kinetics of the anatase-rutile transformation. J. Am. Ceram. Soc. 48, 391-398.

Spacapan, J.B., D’Odorico, A., Palma, O., Galland, O., Vera, E.R., Ruiz, R., Leanza, H.A., Medialdea, A., Manceda, R., 2020. Igneous petroleum systems in the Malargüe fold and thrust belt, Río Grande Valley area, Neuquén Basin, Argentina. Mar. Petrol. Geol. 111, 309-331.

Stoffers, P., Singer, A., Mcmurtry, G., Arquit, A., Hsveh-wen yeh, A., 1990. Geochemistry of a Hydrothermal Nontronite Deposit from the Lau Basin. Southwest Pacific. Geologisches Jahrbuch. Reihe D. Mineralogie, Petrographie, Geochemie, Lagerstättenkunde, pp. 615-628.

Sun, J., Wu, Z., Cheng, H., Zhang, Z., Frost, R.L., 2014. A Raman spectroscopic comparison of calcite and dolomite. Spectrochim. Acta Mol. Biomol. Spectrosc. 117, $158-162$.

Sydnes, M., Fjeldskaar, W., Løtveit, I.F., Grunnaleite, I., Cardozo, N., 2018. The importance of sill thickness and timing of sill emplacement on hydrocarbon maturation. Mar. Petrol. Geol. 89, 500-514. https://doi.org/10.1016/j. marpetgeo.2017.10.017.

Taktak, F., Kharbachi, S., Bouaziz, S., Tlig, S., 2010. Basin dynamics and petroleum potential of the Eocene series in the gulf of Gabes, Tunisia. J. Petrol. Sci. Eng. 75, $114-128$.

Tavarnelli, E., Butler, R.W.H., Decandia, F.A., Calamita, F., Grasso, M., Alvarez, W., Renda, P., Crescenti, U., D'offizi, S., 2004. Implications of fault reactivation and structural inheritance in the Cenozoic tectonic evolution of Italy. Geology (Italy) 1, 209-222.

Teboul, P.-A., Kluska, J.-M., Marty, N.C., Debure, M., Durlet, C., Virgone, A., Gaucher, E. C., 2017. Volcanic rock alterations of the Kwanza Basin, offshore Angola-Insights from an integrated petrological, geochemical and numerical approach. Mar. Petrol. Geol. 80, 394-411.

Touati, M.A., 1985. Etude géologique et géophysique de la concession Sidi El Itayem en Tunisie orientale(Sahel de Sfax): histoire géologique du bassin et évolution de la fracturation et des structures, du Crétacé au Plio-Quaternaire (PhD Thesis).

Tsurumi, J., Hosonuma, H., Kanagawa, K., 2003. Strain localization due to a positive feedback of deformation and myrmekite-forming reaction in granite and aplite mylonites along the Hatagawa Shear Zone of NE Japan. J. Struct. Geol. 25, 557-574.

Wildi, W., 1983. La chaîne tello-rifaine (Algérie, Maroc, Tunisie): structure, stratigraphie et évolution du Trias au Miocène. Rev. Geogr. Phys. Geol. Dyn. 24, 201-297.

Wu, C., Gu, L., Zhang, Z., Ren, Z., Chen, Z., Li, W., 2006. Formation mechanisms of hydrocarbon reservoirs associated with volcanic and subvolcanic intrusive rocks: examples in Mesozoic-Cenozoic basins of eastern China. AAPG Bull. 90, 137-147.

Yuguchi, T., Nishiyama, T., 2008. The mechanism of myrmekite formation deduced from steady-diffusion modeling based on petrography: case study of the Okueyama granitic body, Kyushu, Japan. Lithos 106, 237-260.

Zou, C., 2013. Volcanic Reservoirs in Petroleum Exploration. Newnes. 